\title{
Article \\ HPLC-PDA-ESI-HRMS-Based Profiling of Secondary Metabolites of Rindera graeca Anatomical and Hairy Roots Treated with Drought and Cold Stress
}

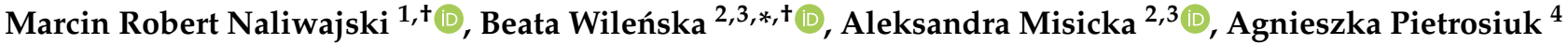 \\ and Katarzyna Sykłowska-Baranek ${ }^{4}$ D
}

check for

updates

Citation: Naliwajski, M.R.;

Wileńska, B.; Misicka, A.;

Pietrosiuk, A.; Sykłowska-Baranek, K. HPLC-PDA-ESI-HRMS-Based

Profiling of Secondary Metabolites of Rindera graeca Anatomical and Hairy

Roots Treated with Drought and Cold Stress. Cells 2022, 11, 931. https:// doi.org/10.3390/cells11060931

Academic Editor:

Suleyman Allakhverdiev

Received: 30 January 2022

Accepted: 3 March 2022

Published: 8 March 2022

Publisher's Note: MDPI stays neutral with regard to jurisdictional claims in published maps and institutional affiliations.

Copyright: (c) 2022 by the authors. Licensee MDPI, Basel, Switzerland. This article is an open access article distributed under the terms and conditions of the Creative Commons Attribution (CC BY) license (https:// creativecommons.org/licenses/by/ $4.0 /)$.
1 Department of Plant Physiology and Biochemistry, Faculty of Biology and Environmental Protection, University of Lodz, 12/16 Banacha St., 90-237 Lodz, Poland; marcin.naliwajski@biol.uni.lodz.pl

2 Faculty of Chemistry, University of Warsaw, 1 Pasteura St., 02-093 Warsaw, Poland; misicka@chem.uw.edu.pl

3 Biological and Chemical Research Centre, 101 Żwirki i Wigury St., 02-097 Warsaw, Poland

4 Department of Pharmaceutical Biology and Medicinal Plant Biotechnology, Faculty of Pharmacy, Medical University of Warsaw, 1 Banacha St., 02-097 Warsaw, Poland; agnieszka.pietrosiuk@wum.edu.pl (A.P.); katarzyna.syklowska-baranek@wum.edu.pl (K.S.-B.)

* Correspondence: bwilenska@chem.uw.edu.pl

+ These authors contributed equally to the work.

\begin{abstract}
To cope with environmental harmful conditions, plant cells developed adaptive strategy that involves production of a wide variety of complex secondary metabolites. The spectrum and quantity of biosynthesized compounds in specific plant species is determined by its genotype, tissue, developmental and physiological stage and environmental factors. This phenomenon was used to exploit the potential of anatomical and hairy root cultures of Rindera graeca to produce bioactive compounds. Cultivated in vitro roots were subjected to abiotic stresses i.e., drought or coldness. Next the extract profiling was performed using HPLC-PDA-ESI-HRMS method, as well quantitative determination of caffeic, rosmarinic and lithospermic B acids, that were present in all root extracts. Phenolic acids, flavonoids and iridoids represent the major groups of compounds detected in chemical profiles growing under various conditions roots. The highest number of phytochemicals was determined in roots subjected to coldness. Lithospermic B acid proved to be the most abundant compound in all investigated extracts. Among applied abiotic stress factors it was demonstrated that coldness affected to the most secondary metabolites production. The results of current study suggest that root cultures of R. graeca could serve as a new and abundant source of lithospermic B acid.
\end{abstract}

Keywords: Boraginaceae rosmarinic acid; lithospermic B acid; abiotic stresses; chemical profile; in vitro cultures; total phenolic and total flavonoid content

\section{Introduction}

In vitro plant cell platforms are continuously explored for application in the biosynthesis of secondary metabolites used as active ingredients of medicines and cosmetics [1-3]. The process of production and accumulation of secondary metabolites is affected by many factors, internal e.g., genetic and biochemical as well as external that is environmental which in turn could and influence the plant metabolome [4]. The environmental factors exert a fundamental effect on the biosynthetic capacities of plant cells that could be transferred to in vitro culture conditions and enable the development of efficient biotechnological approaches to enhance the productivity of bioactive compounds in vitro up to cost-effective levels.

Rindera graeca (A.DC.) Boiss. \& Heldr. (Boraginaceae) is an endemic Greek species growing on rocky slopes at the attitudes of 1500-2300 m [5]. This species is recognized as rare species and placed on the ICUN Red List of Threatened Plants [6]. The chemical profile of aerial parts [7], as well as shoots and roots cultivated in vitro [8-11] of this 
species, has been investigated. These studies revealed the presence of phenolic compounds, pyrrolizidine alkaloids, naphthoquinone shikonin-type compounds and among them rinderol, a potent cytotoxic agent $[7,11,12]$. Rinderol production was optimized in root cultures of R. graeca and its proapoptotic activity was demonstrated [13]. Other various biological activities were also reported for plants of Rindera genus, including antiinflammatory [14], anti-viral [15], and antimicrobial attributed to the presence of essential oils distilled from aerial part [16], in addition the latter were also demonstrated for methanolic and hexane extracts of shoots and hairy roots of $R$. graeca cultivated in vitro as well as rinderol [11].

Plants synthetize a large and diverse group of organic compounds known as secondary metabolites or secondary products. These compounds are often found only in some plant species or a related group of species, while the primary metabolites are found throughout the plant kingdom. For many years the importance of most secondary plant metabolites was unknown. These compounds were considered non-functional end products of metabolism [17]. Currently, many secondary metabolites are recognized as having important ecological functions in plants, such as protecting plants from being eaten by herbivores and against infections by pathogens, or as attractants for pollinators and distribute seeds by animals, and as plant-plant competition agents [17,18].

It has been known for many years that the synthesis and accumulation of metabolites is significantly dependent on growth conditions such as temperature, light, water and nutrient availability, etc. The influence of the environment on the secondary metabolism has also been demonstrated, e.g., various stress factors influence the metabolic pathways responsible for the synthesis of secondary metabolites, leading to their accumulation [18]. Most of the studies that have analyzed the content of secondary metabolites are a comparative analysis between stressed and non-stressed plants, covering only one stress factor in a manner. However, in nature, there are various interferences among many stress factors, such as the increase in light intensity is mainly correlated with elevated temperatures and reduced water availability, as well as associated with higher soil salt level. It has been shown in a wide range of experiments that plants exposed to drought stress do indeed accumulate higher concentrations of secondary metabolites. For example, in response to stress, there is an increase in simple and complex phenols, and many terpenes. The content of nitrogen-containing secondary metabolites such as alkaloids, cyanogenic glycosides and glucosinolates is also increased in response to environmental stresses. There is therefore no doubt that the application of drought stress often increases the concentration of some secondary metabolites. However, it should be taken into account that drought stress also restricts the growth of most plants. Therefore, as a simple and obvious explanation of this effect, it is very often given that under drought stress conditions the same amounts of natural products are synthesized and stored in plants as under normal conditions, but-due to the reduction in biomass - their concentration increase [17-19].

In the current study, the treated with cold and drought stress factors roots of $R$. graeca cultivated in vitro were subjected to the analysis of their secondary metabolite profile using the HPLC-HR-MS method, as well as quantitative assessment of the most abundant phenolic compounds was performed. Additionally, using atomic absorption spectrometry concentration of main plant macro- and microelements such as $\mathrm{Ca}, \mathrm{Mg}, \mathrm{Na}, \mathrm{K}, \mathrm{Fe}$ and $\mathrm{Mn}$ was measured.

\section{Materials and Methods}

\subsection{Root Cultures}

Three root lines of Rindera graeca were subjected for investigation in the current study: an anatomical root line (RgAR), and two hairy root lines (RgTR7 and RgTR17). Root cultures were established by Sykłowska-Baranek et al. [10]. Briefly, the RgAR root line was initiated by cutting off anatomical roots developing on the basis of shoots, hairy root lines were obtained as a result of infection performed with Agrobacterium rhizogenes 15,834. All root cultures were performed in a $250 \mathrm{~mL}$ Erlenmeyer flask containing $50 \mathrm{~mL}$ of liquid 
hormone-free DCR medium [20] and routinely subcultured every four weeks. The cultures were maintained at $23 \pm 1^{\circ} \mathrm{C}$ in the dark at $105 \mathrm{rpm}$ on an INFORS gyratory shaker $105 \mathrm{rpm}$ (INFORS AG, Bottmingen, Switzerland).

\section{Experimental Design}

The 28-day old roots were subjected to drought and cold stress. Each of roots line before stress treatment were transferred to fresh DCR medium.

Each culture of specific root line was divided into three groups: (i) one group was cultivated for 14 days in unchanged conditions (non-treated) and was set as control; (ii) second group was subjected to low temperature of $10^{\circ} \mathrm{C}$ cold stress for 14 days; (iii) third group was subjected for 14 days to drought stress which was induced by medium supplementation with $10 \%$ of polyethylene glycol (PEG) 6000. PEG was dissolved in DCR medium and then filtered by Nalgene ${ }^{\mathrm{TM}}$ Rapid-Flow ${ }^{\mathrm{TM}}$ Sterile Single Use Bottle Top Filters. Roots of the control and drought stressed groups were grown at $23 \pm 1{ }^{\circ} \mathrm{C}$ in the dark at $105 \mathrm{rpm}$ on an INFORS gyratory shaker. For low temperature treatments, roots were transferred to a chamber at $10^{\circ} \mathrm{C}$, in the dark at $105 \mathrm{rpm}$ on an INFORS gyratory shaker.

The elicitation lasted 14 days, next roots were collected, gently pressed on filter paper, and weighted to determine the fresh weight $(\mathrm{FW})$. Afterward, the roots were lyophilized and their dry weight (DW) was recorded. Also the 28-day old roots that was used as a starting material (day " 0 ") for stress experiments were collected, lyophilized and subjected to comparative phytochemical analysis.

\subsection{Extraction of Plant Material}

The powdered lyophilized roots $(100 \mathrm{mg})$ were extracted using ultrasonic bath with $100 \%$ methanol $\left(4 \times 5 \mathrm{~cm}^{3}\right)$ for $1 \mathrm{~h}$ at $25 \pm 5^{\circ} \mathrm{C}$. Afterwards the samples were collected and evaporated to dryness under reduced pressure and stored at $-20^{\circ} \mathrm{C}$. before analysis. Prior to flavonoids and phenols content measurement the dry residue was dissolved in $80 \%$ methanol. Whereas before HPLC-PDA-ESI-HRMS analysis samples were dissolved in $100 \%$ methanol hypergrade for LC-MS LiChrosolv ${ }^{\circledR}$ (Merck; Darmstadt, Germany).

\subsection{HPLC-PDA-ESI-HRMS Analysis}

\subsubsection{Chemicals}

Methanol HPLC LC-MS Grade (CAS no. 67-56-1) and acetic acid (CAS no. 64-19-7) of HPLC Grade were purchased in Merck (Darmstadt, Germany). Methanol (CAS no. 67-56-1) for plant material extraction purchased in Avantor Performance Materials (Poland). Standard substances of rosmarinic (CAS no. 20283-92-5), chlorogenic (CAS no. 327-97-9), caffeic (CAS no. 331-39-5), ferulic (CAS no. 1135-24-6), 3,5-dicaffeoyl-quinic (CAS no. 2450-53-5), sinapic (CAS no. 530-59-6) and $p$-coumaric (CAS no. 501-98-4) acids were purchased in Sigma-Aldrich (Poznań, Poland); 5-O-feruoylouinic acid (CAS no. 113524-6) was purchased in LCG Standards Poland. Lithospermic B acid (CAS 115939-25-8), shikonin (CAS no. 517-88-4), acetylshikonin (CAS no. 24502-78-1), isobutyrylshikonin (CAS no. 52438-12-7), deoxyshikonin (CAS no. 43043-74-9) and isovalerylshikonin (CAS no. 52387-14-1) were purchased in ChemFaces (Wuhan, China).

\subsubsection{HPLC-PDA-ESI-HRMS Analysis}

A Shimadzu Prominence high-performance liquid chromatograph (HPLC) was used coupled with a LCMS-IT-TOF mass spectrometer (Shimadzu Shimadzu Europa GmbH, Duisburg, Germany), equipped with an ion trap (IT), a time-of-flight (TOF) detector and an electrospray ionization (ESI) source. Mass spectra were recorded in the positive and negative ion modes using LCMSsolution software (Shimadzu Shimadzu Europa GmbH, Duisburg, Germany).

Conditions for HPLC separation and detection of extracts were as follows: column Kinetex $\mathrm{C}_{18}, 2.6 \mu \mathrm{m}, 2.1 \mathrm{~mm} \times 100 \mathrm{~mm}$ (Phenomenex, Torrance, CA, USA), injection volume: $3 \mu \mathrm{L}$, oven column temperature: $40^{\circ} \mathrm{C}$, flow rate: $0.2 \mathrm{~mL} / \mathrm{min}$, analysis duration: 
$75 \mathrm{~min}$, PDA detection at wavelengths $\lambda=200-800 \mathrm{~nm}$. The mobile phase consisted of (A) water with the addition of $0.2 \% \mathrm{CHCOOH}$ and (B) methanol. The following gradient was applied: $0-10 \min 5 \%$ B, $10-30$ min $5 \rightarrow 50 \%$ B, 30-35 min $50 \rightarrow 50 \%$ B, 35-55 min $50 \rightarrow 95 \%$ B, $55-60 \min 95 \%$ B, $60-62 \min 95 \rightarrow 5 \%$ B, equilibrium time- -13 min in $5 \%$ B.

Conditions for the mass spectrometer were as follows: polarity positive and negative, mass range $m / z 100-1000$ Da in both modes, ion accumulation time: $10 \mathrm{~ms}$ in MS1 experiments and $25 \mathrm{~ms}$ in MS2 experiments, interface temperature: $220^{\circ} \mathrm{C}$, heat block temperature: $220^{\circ} \mathrm{C}$, nebulizing gas flow: $1.5 \mathrm{~L} / \mathrm{min}$, drying gas pressure: $100 \mathrm{kPa}$, IS: $+4.5 \mathrm{kV}$ (positive mode) and IS: $-3.0 \mathrm{kV}$ (negative mode), collision energy in MS2 experiments: $25-35 \%$.

The TOF detector of the LCMS-IT-TOF mass spectrometer for high resolution mass spectrometry experiments (HRMS) was calibrated with mixture of standard compounds. For all standard samples mass spectra and fragmentation mass spectra were acquired for identification and confirmation of compounds presented in the methanolic extracts. In that case a HRMS experiment was also used for confirmation of molecular formula. In all HRMS experiments a difference between theoretical and measurement $m / z$ value was below $5 \mathrm{ppm}$. For the unknown compounds a HRMS experiment was the only one method, which was applied for prediction of the most likely molecular formula.

\subsubsection{Standard Sample Preparation}

For the calibration curve six calibration standard samples were prepared in the form of a mixture consisting of caffeic acid (CA), rosmarinic acid (RA) and lithospermic $B$ acid (LBA). Concentrations of acids were as follows: caffeic acid in a range of $3.46-111.11 \mu \mathrm{g} / \mathrm{mL}$, rosmarinic acid in a range of 3.82-122.22 $\mu \mathrm{g} / \mathrm{mL}$, and lithospermic B acid in a range of $4.38-1.26 \mu \mathrm{g} / \mathrm{mL}$. All acids were prepared by independent dissolving about $1 \mathrm{mg}$ of each acid in $1 \mathrm{~mL}$ of methanol and prepared standard mixtures with concentrations around $1 \mathrm{mg} / \mathrm{mL}$ were used for calibration mixture preparation.

The methanolic extract was prepared by dissolving in $300 \mu \mathrm{L}$ of methanol and spinning on vortex, and the supernatant was transferred to an HPLC injection vial.

\subsubsection{HPLC Method Validation}

The developed method was validated in terms of linearity, specificity, precision, accuracy (recovery) as well as precision and accuracy of Limit of quantification (LOQ).

Analytical specificity was assessed by comparison of UV chromatograms recorded for a blank sample, standard sample and test sample (Figure S1a).

To asses linearity of the assay, six-level calibrators were analyzed. The calibration curve was established by the linear fit of the peak area ratio versus concentration. For each acid an independent calibration curve was established (Figure S1b-d). In the case of caffeic acid a calibration curve crosses zero.

LOQ was determined as the lowest concentration used for calibration curve preparation with accuracy within accuracy (recovery) within $\pm 20 \%$ of true value and precision below $5 \%$.

Assay precision and accuracy (recovery) were determined by sevenfold analysis of the test sample and test sample spiked with standards, respectively. In accuracy assays, seven individual test samples with low concentration of endogenous acids were spiked with known amount of caffeic, rosmarinic and lithospermic B acid. Recovery was expressed as a percentage of increased concentration and true added value of acid. The results of method validation are presented in Figure S1.

\subsection{Determination of Total Flavonoid Content (TFC)}

Total flavonoid content was determined colorimetrically based on the reaction following procedures from Pękal and Pyrzyńska [21] with modifications described by Śliwińska et al. [17]. Briefly, extracts or standard (quercetin, QE), were mixed with $5 \%$ of sodium nitrate. After 5 min of incubation, 2\% aluminum chloride were added and allowed to incubate for another $5 \mathrm{~min}$, 
after which, $1 \mathrm{M}$ sodium hydroxide were added to the mixture. The evaluation of absorbance for TPC calculations was measured spectrophotometrically at $425 \mathrm{~nm}$. Results are reported as $\mathrm{mg}$ of $\mathrm{QE}$ equivalents per $1 \mathrm{~g}$ of drought weight $(\mathrm{mg} \mathrm{QE} / \mathrm{g} \mathrm{DW})$ using the regression equation determined from the standard curve: $y=0.0021 x+0.0072, \mathrm{r}^{2}=0.9937$.

\subsection{Determination of Total Phenolic Compounds Content (TPC)}

The total phenolic compounds content was determined colorimetrically based on the Folin-Ciocalteu [16] with some modification as described Śliwińska et al. [17]. Samples of each extract or standard (gallic acid, GAE) were mixed with the Folin-Ciocalteu reagent, shaked, and mixed with $7 \%$ sodium carbonate. All reactions were done in triplicates. A standard GAE curve was prepared as a comparative reference. Results are reported as mg of GAE equivalents per $1 \mathrm{~g}$ of drought weight (mg GAE/g DW) using the regression equation determined from the standard curve: $y=0.0088 x-0.0846, r^{2}=0.9947$. The evaluation of absorbance for TPC calculations was measured spectrophotometrically at $765 \mathrm{~nm}$.

\subsection{Determination of Ions Concentration}

The following ions concentrations: $\mathrm{Ca}, \mathrm{Mg}, \mathrm{Na}, \mathrm{K}, \mathrm{Fe}$ and $\mathrm{Mn}$, were determined in roots by atomic absorption spectrometry (SpektrAA 300, Varian, Mulgrave, Australia) following wet digestion of $50 \mathrm{mg}$ of oven dried plant tissue samples in $5 \mathrm{~mL}$ of $69 \% \mathrm{HNO}_{3}$ at $140{ }^{\circ} \mathrm{C}$.

\subsection{Statistical Analysis}

Nine biological replicates per treatment and three for time zero cultures were used for growth, TPC and TFC statistical analysis. Whereas for analytical examination six replicates per treatment and three for time zero cultures were used. Determination of ion concentration was performed based on five replicates. Data represents mean values \pm standard deviation (SD). The statistical significance between means was assessed using the Kruskal-Wallis one-way analysis of variance performed with STATISTICA 13.1 PL (StatSoft, Kraków, Poland) software. Significance between groups was further estimated using the Mann-Whitney U test. A probability of $p<0.05$ was considered significant. Pairwise metabolite-antioxidant effects correlations were calculated by Pearson's correlation coefficient test.

\section{Results and Discussion}

\subsection{Biomass, Total Phenols and Flavonoids as Well as Ions Concentration}

The effect of abiotic stress on biomass accumulation varied according to root line. Only in RgAR roots both stresses caused growth of fresh weight (FW) by $56 \%$ and $5 \%$ in response to drought or cold stress, respectively. In opposite, under cold stress condition the decrease in FW by 55\% and 42 \% was observed in RgTR7 and RgTR17 root lines, respectively (Table 1 ).

Dry weight analysis indicates that only in response to cold stress biomass decreased by 39\% (RgAR), 51\% (RgTR7) and 39\% (RgTR17) in comparison to control cultures (Table 1). 
Table 1. Biomass [mg] of R. graeca roots cultivated under various conditions.

\begin{tabular}{|c|c|c|c|c|c|c|c|c|c|c|c|c|}
\hline \multirow{3}{*}{$\begin{array}{l}\text { Treatment } \\
\text { FW/DW }\end{array}$} & \multicolumn{3}{|c|}{28 Day Old Roots-Time “0” } & \multicolumn{3}{|c|}{ Control } & \multicolumn{3}{|c|}{ Drought Stress } & \multicolumn{3}{|c|}{ Cold Stress } \\
\hline & \multicolumn{12}{|c|}{ Root Line } \\
\hline & RgAR & RgTR7 & RgTR17 & RgAR & RgTR7 & RgTR17 & RgAR & RgTR7 & RgTR17 & RgAR & RgTR7 & RgTR17 \\
\hline FW & $\begin{array}{c}1835.7 \pm \\
103.0 *\end{array}$ & $\begin{array}{c}1040.3 \pm \\
387.6^{*}\end{array}$ & $\begin{array}{c}2068.1 \pm \\
239.7^{*}\end{array}$ & $\begin{array}{c}2138.7 \pm \\
573.8^{\mathrm{a} *}\end{array}$ & $\begin{array}{c}3550.7 \pm \\
854.7^{\mathrm{b} *}\end{array}$ & $\begin{array}{l}4708.4 \pm \\
421.1^{\mathrm{c} *}\end{array}$ & $\begin{array}{c}3344.3 \pm \\
454.3^{*}\end{array}$ & $\begin{array}{c}3280.8 \pm \\
879.9^{*}\end{array}$ & $\begin{array}{c}3732.6 \pm \\
525.8\end{array}$ & $\begin{array}{c}2241.2 \pm \\
254.7^{\mathrm{a}}\end{array}$ & $\begin{array}{c}1683.6 \pm \\
685.2^{\mathrm{b}}\end{array}$ & $\begin{array}{c}2740.0 \pm \\
408.5^{\mathrm{c}}\end{array}$ \\
\hline DW & $360.9 \pm 23.6$ & $229.9 \pm 92.1$ & $359.5 \pm 13.5$ & $664.3 \pm 79.6$ & $621.7 \pm 144.2$ & $767.8 \pm 35.7$ & $654.9 \pm 61.4$ & $646.2 \pm 153.1$ & $700.3 \pm 62.2$ & $408.1 \pm 41.7$ & $305.7 \pm 134.7$ & $470.2 \pm 55.5$ \\
\hline
\end{tabular}

FW—-fresh weight; DW—dry weight; RgAR—anatomical roots; RgTR7—hairy root line TR7; RgTR17—hairy root line TR17; time "0"—28-day-old roots at time of inoculation; Control—roots cultivated without any treatment for 14 days; Drought stress—roots treated by drought stress for 14 days; Cold stress—roots treated by cold stress for 14 days. Means denoted with the same letter or asterisk are statistically significant $(p<0.05)$. The same letters indicate statistically significant differences $(p \leq 0.05)$ in relation to control within the same root lines between treatments. Asterisks $\left.{ }^{*}\right)$ indicate statistically significant differences $(p \leq 0.05)$ in relation to time " 0 " within the same root lines between treatments. 
In current study the inhibition of root biomass accumulation under cold stress was observed. The decreasing biomass in response to this stress was also reported e.g., in rice [22]. Further, the lack of changes in biomass growth under drought stress could be probably linked with the adaptation effect of this plant species to its natural environment, which is rocky mountains of Greece. Usually, chilling and freezing stresses limits the growth and development of plants, and reduce primary metabolism and cause e.g., a violation of the stability of proteins or protein complexes and a decrease in enzymatic activity [23].

Generally in the plants, the same amounts of ions are absorbed or metabolites are synthesized and accumulated, as under well-watered conditions, but-due to the reduction in biomass-their concentration simply is elevated [17]. Both used stressors did not significantly influence on the changes in the ions concentration between stressed roots and respective controls (Table 2).

Total phenolic compounds concentration (TPC) in unstressed RgAR and RgTR17 were significantly lower by about $65 \%$ than in RgAR " 0 " and RgTR 17 " 0 ", respectively (Figure 1a). In response to drought stress TPC significantly decrease by $65-77 \%$ in each of examined root lines in compare to RgAR " 0 ", RgTR7 " 0 " and RgTR17 " 0 ". The lowest significant changes in phenols concentration in the RgAR root line was observed after cold stress treatment and was lower by $6 \%$ than in $\operatorname{RgAR}$ " 0 " and RgAR.

In the anatomical root line both stresses did not cause changes in total flavonoids concentration. The concentration of this compounds significantly decreased in RgTR7 and drought stressed RgTR7 by about 72\% in compare to RgTR7 " 0 ". Similarly in RgTR7 and drought stressed RgTR7 were observed decrease of total flavonoids by $51-62 \%$ in compare to RgTR7 “ 0 ” (Figure 1b).

The results of TPC, TFC and HPLC analysis are consistent. Three selected for quantitative determination phenolic acids are part of the total pool of phenolic compounds that is estimated to exceed 8000 molecules [24], among others are phenolic acids and flavonoids. The highest concentration of investigated compounds determined in roots used for inoculation could be attributed to observed in plant in vitro cultures distinct lag phase when biosynthesis of secondary metabolites is performed at very low levels [25], which was also observed under conditions of present study. The abiotic stress factors applied acted for 14 days and did not affected significantly TPC and TFC accumulation in relation to control. 
Table 2. Ions concentration [ppm/g DW] in R. graeca roots cultivated under various conditions.

\begin{tabular}{|c|c|c|c|c|c|c|c|c|c|c|c|c|}
\hline \multirow{2}{*}{ Treatment } & \multicolumn{3}{|c|}{28 Day Old Roots-Time “0" } & \multicolumn{3}{|c|}{ Control } & \multicolumn{3}{|c|}{ Drought Stress } & \multicolumn{3}{|c|}{ Cold Stress } \\
\hline & \multicolumn{12}{|c|}{ Root Line } \\
\hline Ion & RgAR & RgTR7 & RgTR17 & RgAR & RgTR7 & RgTR17 & RgAR & RgTR7 & RgTR17 & RgAR & RgTR7 & RgTR17 \\
\hline $\mathrm{Ca}$ & $3.37 \pm 0.81$ & $1.64 \pm 0.12$ & $2.81 \pm 0.55$ & $2.64 \pm 0.42$ & $2.12 \pm 0.20$ & $2.90 \pm 0.17^{a}$ & $2.50 \pm 0.25$ & $2.27 \pm 0.34$ & $2.24 \pm 0.40$ & $2.50 \pm 0.31$ & $1.90 \pm 0.19^{a}$ & $2.66 \pm 0.27$ \\
\hline $\mathrm{Mg}$ & $1.36 \pm 0.27$ & $0.76 \pm 0.03$ & $1.29 \pm 0.29$ & $1.17 \pm 0.19$ & $1.06 \pm 0.14$ & $1.41 \pm 0.09 * a, b$ & $1.04 \pm 0.11$ & $0.87 \pm 0.15^{\mathrm{a}}$ & $0.90 \pm 0.17$ & $1.06 \pm 0.06$ & $0.87 \pm 0.06^{b}$ & $1.20 \pm 0.11$ \\
\hline $\mathrm{Na}$ & $2.53 \pm 0.16$ & $2.51 \pm 0.28$ & $2.37 \pm 0.07$ & $2.47 \pm 0.11$ & $2.33 \pm 0.18$ & $2.19 \pm 0.07$ & $2.20 \pm 0.10$ & $2.11 \pm 0.70$ & $2.09 \pm 0.07^{a, b}$ & $2.82 \pm 0.18^{\mathrm{a}}$ & $2.78 \pm 0.36^{\mathrm{b}}$ & $2.52 \pm 0.12$ \\
\hline $\mathrm{K}$ & $11.29 \pm 1.09$ & $11.25 \pm 0.29$ & $11.11 \pm 1.85$ & $13.37 \pm 0.68^{\mathrm{a}, \mathrm{b}}$ & $12.35 \pm 0.53$ & $11.42 \pm 0.54$ & $10.93 \pm 0.41$ & $10.29 \pm 0.77^{a}$ & $9.57 \pm 1.15^{\mathrm{b}}$ & $10.91 \pm 2.57$ & $12.89 \pm 0.70$ & $12.74 \pm 1.41$ \\
\hline $\mathrm{Fe}$ & $0.35 \pm 0.04$ & $0.30 \pm 0.04$ & $0.27 \pm 0.01$ & $0.26 \pm 0.02$ & $0.21 \pm 0.02$ & $0.23 \pm 0.02$ & $0.22 \pm 0.03$ & $0.23 \pm 0.04$ & $0.17 \pm 0.02 \mathrm{a}, \mathrm{a}, \mathrm{c}$ & $0.29 \pm 0.05^{\mathrm{a}}$ & $0.33 \pm 0.05^{b}$ & $0.29 \pm 0.03^{c, b}$ \\
\hline $\mathrm{Mn}$ & $0.38 \pm 0.04$ & $0.33 \pm 0.01$ & $0.34 \pm 0.02$ & $0.31 \pm 0.03$ & $0.29 \pm 0.01$ & $0.30 \pm 0.01$ & $0.27 \pm 0.01$ & $0.25 \pm 0.03^{\mathrm{a}, \mathrm{b}}$ & $0.22 \pm 0.03$ & $0.34 \pm 0.01^{\mathrm{a}}$ & $0.32 \pm 0.02$ & $0.34 \pm 0.02^{b}$ \\
\hline
\end{tabular}

RgAR—anatomical roots; RgTR7—hairy root line TR7; RgTR17—hairy root line TR17; time "0"—-28-day-old roots at time of inoculation; Control—roots cultivated without any treatment for 14 days; Drought stress - roots treated by drought stress for 14 days; Cold stress-roots treated by cold stress for 14 days. Means denoted with the same letter or asterisk are statistically significant $(p<0.05)$. Asterisks $\left(^{*}\right)$ indicate statistically significant differences $(p \leq 0.05)$ in relation to control within the same root lines between treatments. The same letters indicate statistically significant differences $(p<0.05)$ between different root lines. 


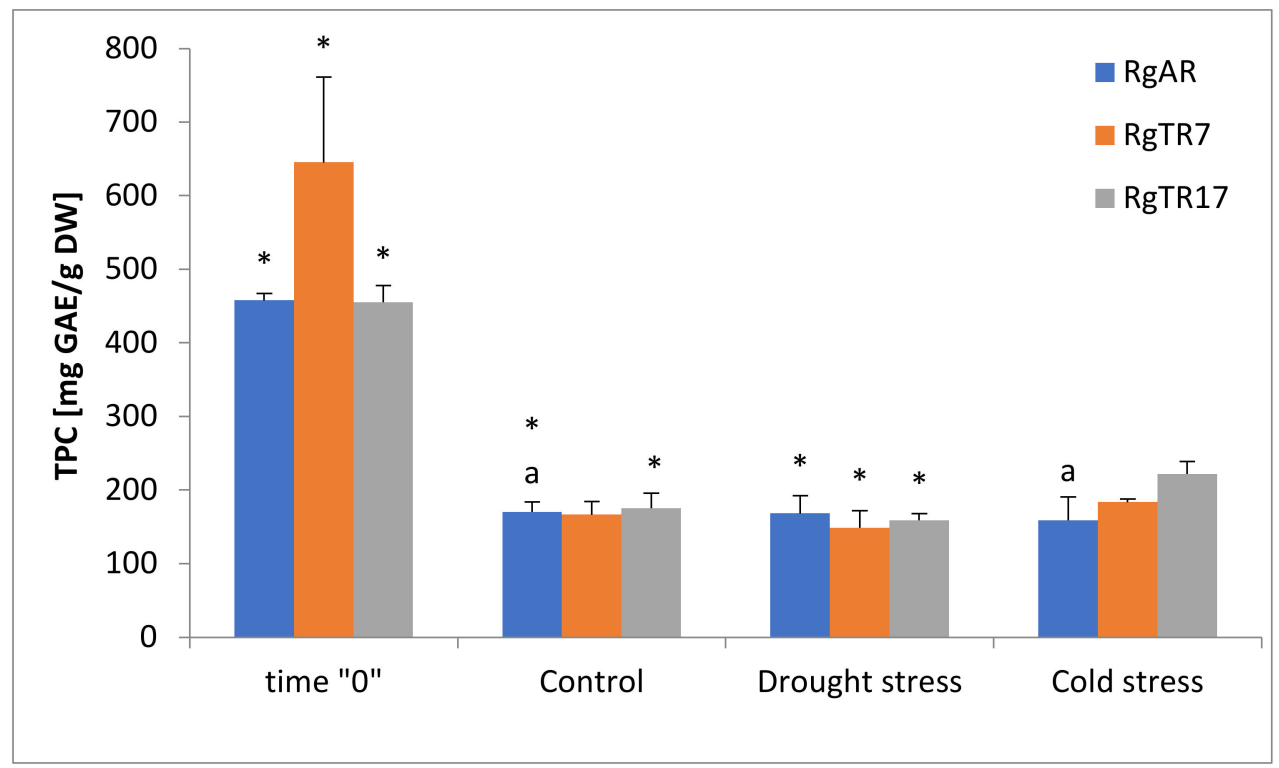

(a)

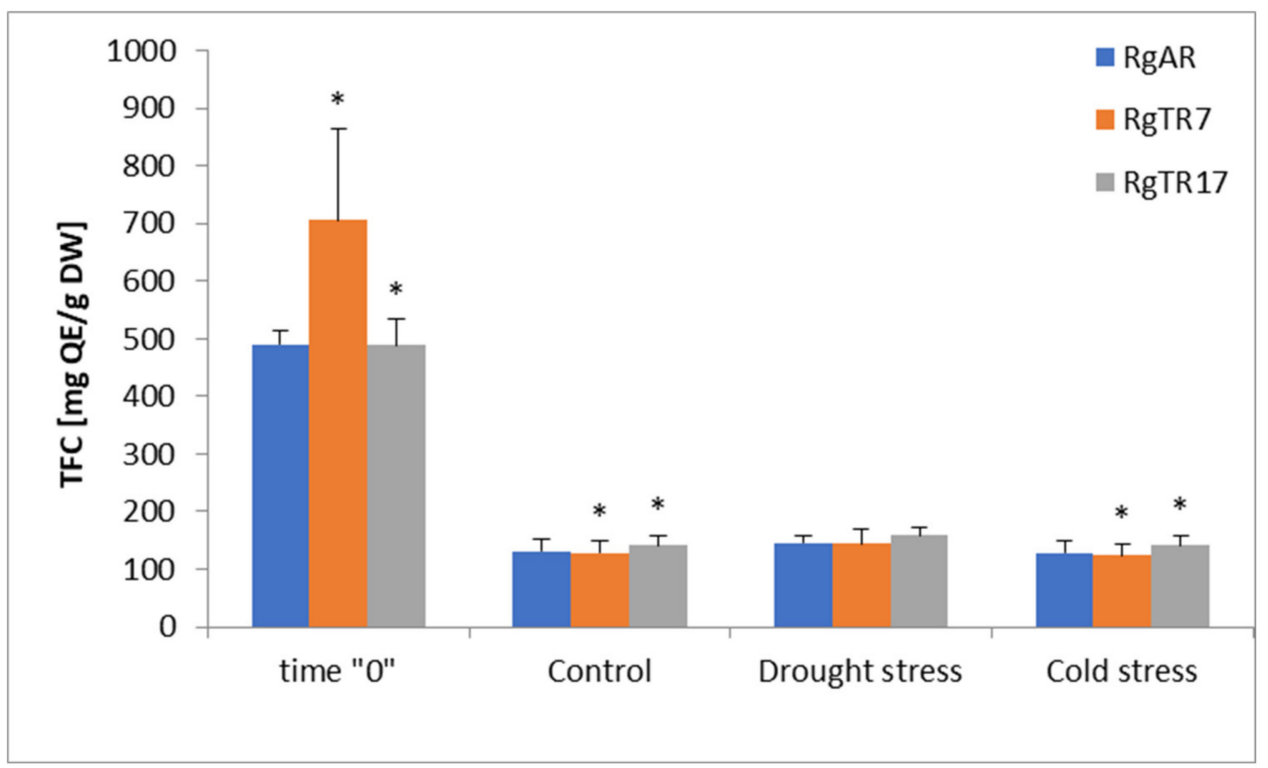

(b)

Figure 1. (a) Total phenolic (TPC) and (b) total flavonoid (TFC) content determined in R. graeca roots cultivated under various conditions. RgAR — anatomical roots; RgTR7—hairy root line TR7; RgTR17-hairy root line TR17; time " 0 "-28-day-old roots at time of inoculation; Control—roots cultivated without any treatment for 14 days; Drought stress-roots treated by drought stress for 14 days; Cold stress-roots treated by cold stress for 14 days. The same letters indicate statistically significant differences $(p \leq 0.05)$ in relation to control within the same root lines between treatments. Asterisks $\left({ }^{*}\right)$ indicate statistically significant differences $(p \leq 0.05)$ in relation to time " 0 " within the same root lines between treatments.

\subsection{HPLC-PDA-ESI-HRMS Analysis}

The HPLC-PDA-ESI-HRMS analysis of methanolic extracts derived from roots cultivated in control and drought or cold stress treated root cultures was performed to determine 16 standard compounds (Table 3). The major constituents of investigated extracts were caffeic (CA), rosmarinic (RA) and lithospermic B acid (LAB) and their concentration in 
root extracts was determined. The validation parameters elaborated for quantitative HPLC analysis of three phenolic acids, i.e., CA, RA and LAB are presented in Figure S1.

Table 3. The presence of standard compounds in Rindera graeca root extracts determined by HPLCPDA-ESI-HRMS analysis.

\begin{tabular}{|c|c|c|c|c|c|c|c|c|c|c|c|c|}
\hline \multirow{3}{*}{$\begin{array}{l}\text { Treatment } \\
\text { Compound } \\
\end{array}$} & \multicolumn{3}{|c|}{$\begin{array}{l}28 \text { Day Old Roots-Time } \\
\text { "0" }\end{array}$} & \multicolumn{3}{|c|}{ Control } & \multicolumn{3}{|c|}{ Drought Stress } & \multicolumn{3}{|c|}{ Cold Stress } \\
\hline & \multicolumn{12}{|c|}{ Root Line } \\
\hline & RgAR & RgTR7 & RgTR17 & RgAR & RgTR7 & RgTR17 & RgAR & RgTR7 & RgTR17 & RgAR & RgTR7 & RgTR17 \\
\hline Caffeic acid & + & + & + & + & + & + & + & + & + & + & + & + \\
\hline Chlorogenic acid & - & - & - & - & - & - & - & - & - & - & - & - \\
\hline$p$-coumaric acid & - & - & - & - & - & - & - & - & - & - & - & - \\
\hline 5-O-feruoylo-quinic acid & - & - & - & - & - & - & - & - & - & - & - & - \\
\hline Sinapic acid & - & - & - & - & - & - & - & - & - & - & - & - \\
\hline 3,5-dicaffeoyl-quinic acid & - & - & - & - & - & - & - & - & - & - & - & - \\
\hline Rosmarinic acid & + & + & + & + & + & + & + & + & + & + & + & + \\
\hline Lithospermic acid & - & - & + & - & - & + & - & - & + & - & - & + \\
\hline Lithospermic B acid & + & + & + & + & + & + & + & + & + & + & + & + \\
\hline Shikonin & - & - & - & - & - & - & - & - & - & - & - & - \\
\hline Acetylshikonin & - & - & - & - & - & - & - & - & - & - & - & - \\
\hline Isobutyrylshikonin & - & - & - & - & - & - & - & - & - & - & - & - \\
\hline Deoxyshikonin & - & - & - & - & - & - & - & - & - & - & - & - \\
\hline Isovalerylshikonin & - & - & - & - & - & - & - & - & - & - & - & - \\
\hline Dimethylacrylshikonin & - & - & - & - & - & - & - & - & - & - & - & - \\
\hline Rinderol & + & - & + & - & - & - & - & - & - & - & - & - \\
\hline
\end{tabular}

RgAR—anatomical roots; RgTR7—hairy root line TR7; RgTR17—hairy root line TR17; time "0"—-28-day-old roots at time of inoculation; Control—roots cultivated without any treatment for 14 days; Drought stress—roots treated by drought stress for 14 days; Cold stress—roots treated by cold stress for 14 days.

For all standard samples mass spectra and fragmentation mass spectra were acquired for identification and confirmation of compounds presented in the methanolic extracts. In addition, HRMS experiment was also used for confirmation of molecular formula. Further, the profiling of extracts by HRMS method was carried out, and prediction of the most likely molecular formula of detected compounds was done (Table S1-S3). In all HRMS experiments a difference between theoretical and measurement $m / z$ value was below $5 \mathrm{ppm}$ (Table S4). The compounds annotation was performed based on the Pub Chem database. The structures were proposed in accordance with recorded HRMS measurements that consisted of finding the most suitable molecular formulas with mass accuracy below $5 \mathrm{ppm}$. Moreover, in the Pub Chem database, a lot of additional information like provenance and compounds class were published, which were also used for the identification of compounds found in methanolic extracts. All of the proposed structures were known in literature and were also detected in various parts of different plants.

Irrespectively root line, the highest content of investigated phenolic acids was determined in 28-day old roots that is at time zero (Table 4). The quantitative analysis of CA, RA and LAB in root extracts revealed that LBA was the most abundant phenolic acid accumulated. At this time point the LBA content was the highest in RgTR7 roots (106.07 \pm $10.65 \mathrm{mg} / \mathrm{g}$ DW) and was almost 1.7- and over 1.2-fold higher than in RgAR and RgTR17 roots, respectively. RA concentration was also the highest in roots of RgTR7 line, although its concentration was lower than LAB content almost 5-, 3- and 8-fold in RgAR, RgTR7 and RgTR17 roots, respectively. CA was present in the lowest concentration in investigated root extracts. 
Table 4. Phenolic acid content [mg/g DW] in R. graeca roots cultivated under various conditions.

\begin{tabular}{|c|c|c|c|c|c|c|c|c|c|c|c|c|}
\hline \multirow{3}{*}{$\begin{array}{l}\text { Treatment } \\
\text { Compound } \\
\end{array}$} & \multicolumn{3}{|c|}{28 Day Old Roots-Time “" } & \multicolumn{3}{|c|}{ Control } & \multicolumn{3}{|c|}{ Drought Stress } & \multicolumn{3}{|c|}{ Cold Stress } \\
\hline & \multicolumn{12}{|c|}{ Root Line } \\
\hline & RgAR & RgTR7 & RgTR17 & RgAR & RgTR7 & RgTR17 & RgAR & RgTR7 & RgTR17 & RgAR & RgTR7 & RgTR17 \\
\hline Caffeic acid & $0.20 \pm 0.01$ & $0.01 \pm 0.01$ & $0.24 \pm 0.04$ & $0.03 \pm 0.005$ & $0.03 \pm 0.005^{*}$ & $0.04 \pm 0.01$ * & $0.06 \pm 0.15$ & $0.05 \pm 0.01 *$ & $0.09 \pm 0.02 *$ & $0.08 \pm 0.02$ & $0.05 \pm 0.01$ & $0.08 \pm 0.01^{\mathrm{a}}$ \\
\hline $\begin{array}{l}\text { Rosmarinic } \\
\text { acid }\end{array}$ & $12.74 \pm 0.12$ & $33.69 \pm 15.11$ & $10.97 \pm 1.24$ & $0.95 \pm 0.08$ & $0.90 \pm 2.45$ & $0.52 \pm 0.23$ & $0.87 \pm 0.10$ & $0.99 \pm 0.60$ & $0.48 \pm 0.24$ & $2.50 \pm 0.98^{*}$ & $0.60 \pm 0.14^{*}$ & $1.31 \pm 0.50$ \\
\hline $\begin{array}{c}\text { Lithospermic B } \\
\text { acid }\end{array}$ & $63.17 \pm 17.68$ & $106.07 \pm 10.65$ & $87.77 \pm 14.71$ & $2.05 \pm 0.43^{\mathrm{a}}$ & $1.68 \pm 0.79^{\mathrm{b}}$ & $2.01 \pm 0.32^{c}$ & $2.13 \pm 0.34$ & $1.76 \pm 0.67$ & $1.71 \pm 0.08^{\mathrm{c}}$ & $31.78 \pm 7.08^{\mathrm{a}, *}$ & $5.67 \pm 2.37^{b, *}$ & $7.39 \pm 1.12^{\mathrm{c}, *}$ \\
\hline
\end{tabular}


In all examined root lines stresses caused increase in concentration of CA. In response to drought or cold, in the RgAR concentration of this compound grew by $100 \%$ and $167 \%$, respectively. In the RgTR7 both stresses caused growth of CA by $67 \%$. The level of C A in RgTR17 increased by $125 \%$ and $100 \%$ after drought and cold stress treatment, respectively. In compare to CA, RA production presented different dynamic of changes. Only in cold stressed roots concentration of RA increased by $163 \%$ (RgAR) and $152 \%$ (RgTR17) in compare to respective control. The concentration of this acid in cold stressed RgTR7 decrease by $33 \%$ than in control.

In response to cold stress the high growth of LAB by 237\% (RgTR7) and 268\% (RgTR17) than in controls was observed whereas level of this compounds in RgAR increased 15-fold than in unstressed RgAR (Table 4). The production of LBA was mostly reported for plants of Lamiaceae family $[25,26]$, with one study describing its and RA accumulation in hairy root cultures of Lithospermum erythrorhizon [27]. Nevertheless, the yield of LBA reported in current study substantially exceeds its previously reported productivity.

Abiotic stresses, including drought and low temperature ones, are broadly used to improve production of secondary metabolites or induce de novo their biosynthesis [28]. The significant role in production of secondary metabolites under stress condition is attributed to generation of oxidative stress defense response [29,30]. In turn to cope with excessive production of reactive oxygen species (ROS) generated induction of secondary metabolites biosynthesis is initiated.

The present study analysis of metabolome showed variation in chemical profiles between investigated root lines treated with various stress conditions (Figures 2-4; Tables 5-7). However, the majority of metabolites biosynthesized by root of the same line were similar and the patter of compounds detected was similar. The main groups of secondary metabolites produced in response to stresses applied belongs to flavonoids, phenolic compounds and iridoids, that is metabolites that were reported to play crucial role in plant cell protection against detrimental environmental factors [28,31,32]. Many of compounds detected in chemical profiles of investigated root lines, as well quantitative analysis of $C A$, RA and LBA are reported for the first time in $R$. graeca root extracts [7,11]. The results of present study are not consistent with the previous report describing chemical prolife of $R$. graeca roots cultivated in vitro [11], that noted lack of LAB and chlorogenic acid. While in present study LAB was the major secondary metabolite accumulated in roots. However, RA yield determined in roots cultivated under conditions of present study was considerably lower than that quantified in R. lanata aerial parts [15]. Further, in present study no quercetin 3-rutinoside-7-rhamnoside or pyrrolizidine alkaloids were detected which were also previously found in $R$. graeca $[7,11]$ and other species of this genus [33,34]. None of the compounds detected in investigated root extracts obtained under conditions of this study was documented before in Rindera genus. In examined $R$. graeca root extracts no shikonin derivatives were detected (Table 3 ). This phenomena was earlier reported in cell suspension cultures of L. erythrorhizon [35]. Authors suggest that in specific culture conditions, in LBA and shikonin biosynthetic pathway, in which they share its early steps, the phenylpropanoid unit is further favorably used for LBA synthesis. Nevertheless under conditions of this study in two samples of 28-day old roots: RgAR and hairy of RgTR17 line was detected rinderol, a furano-naphthoquinone compound demonstrating antiapoptotic potential [13]. Previously rinderol was determined both in RgTR7 and RgTR17 28-old-day root lines cultivated in vitro [11], but in further subcultures its biosynthesis was induced only in cultures carried out on polyurethane rafts [11]. Such gradual loss of biosynthetic capacity, could be attributed to genetic and epigenetic variation during long-term cultivation in vitro [36,37], which is believed to be the main cause of decrease in secondary metabolites production abilities. 


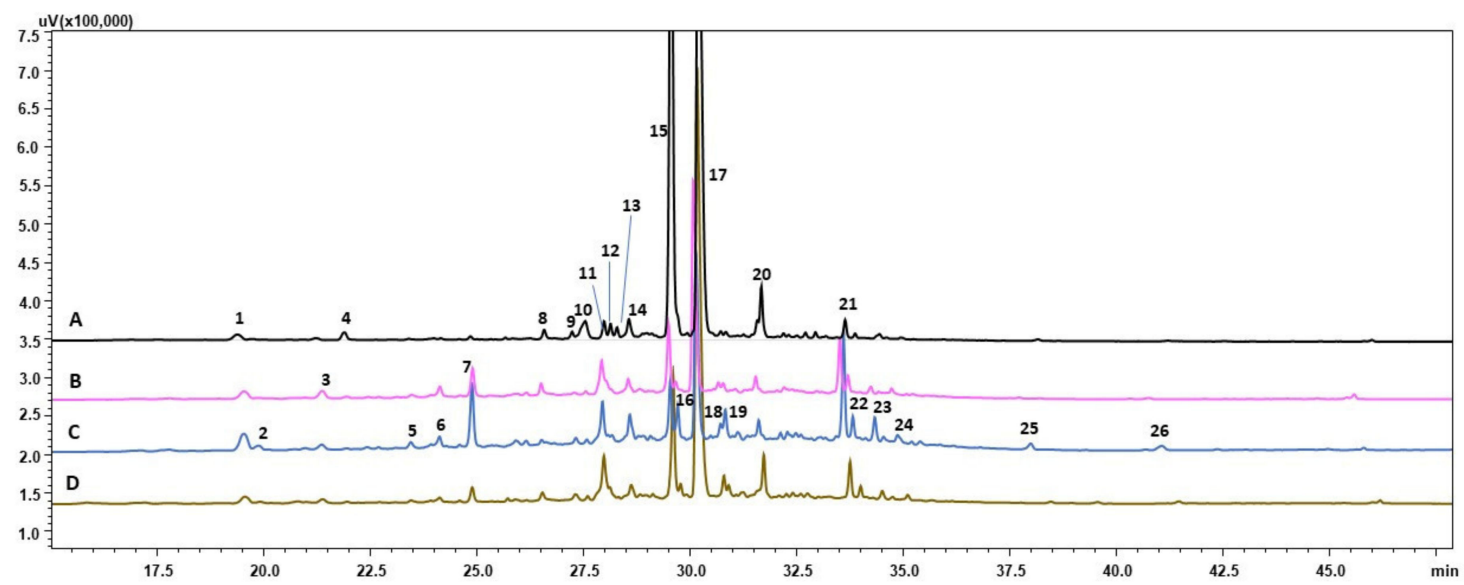

Figure 2. HPLC-PDA chromatograms (wavelength $320 \mathrm{~nm}$ ) of RgAR line root extracts: (A) 28-day-old (time zero); (B) 14-day old untreated roots-control; (C) roots treated 14 days with drought stress; (D) roots treated 14 days with cold stress.

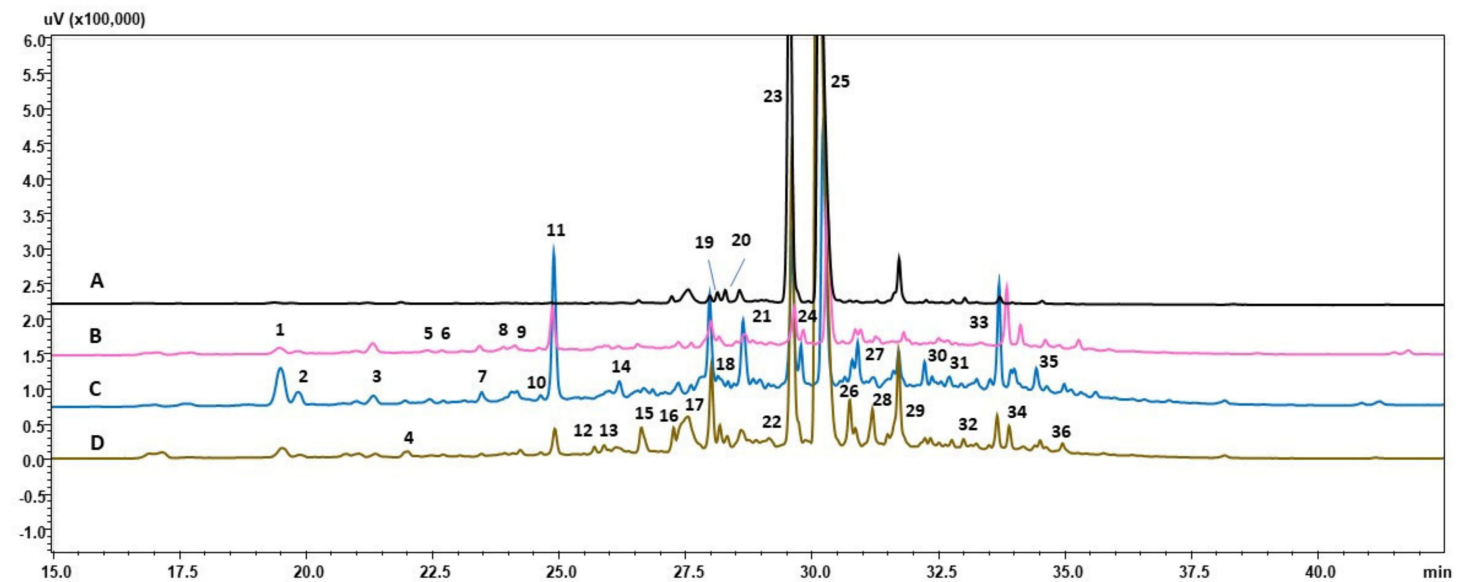

Figure 3. HPLC-PDA chromatograms (wavelength $320 \mathrm{~nm}$ ) of RgTR7 line root extracts: (A) 28-dayold (time zero); (B) 14-day old untreated roots-control; (C) roots treated 14 days with drought stress; (D) roots treated 14 days with cold stress.

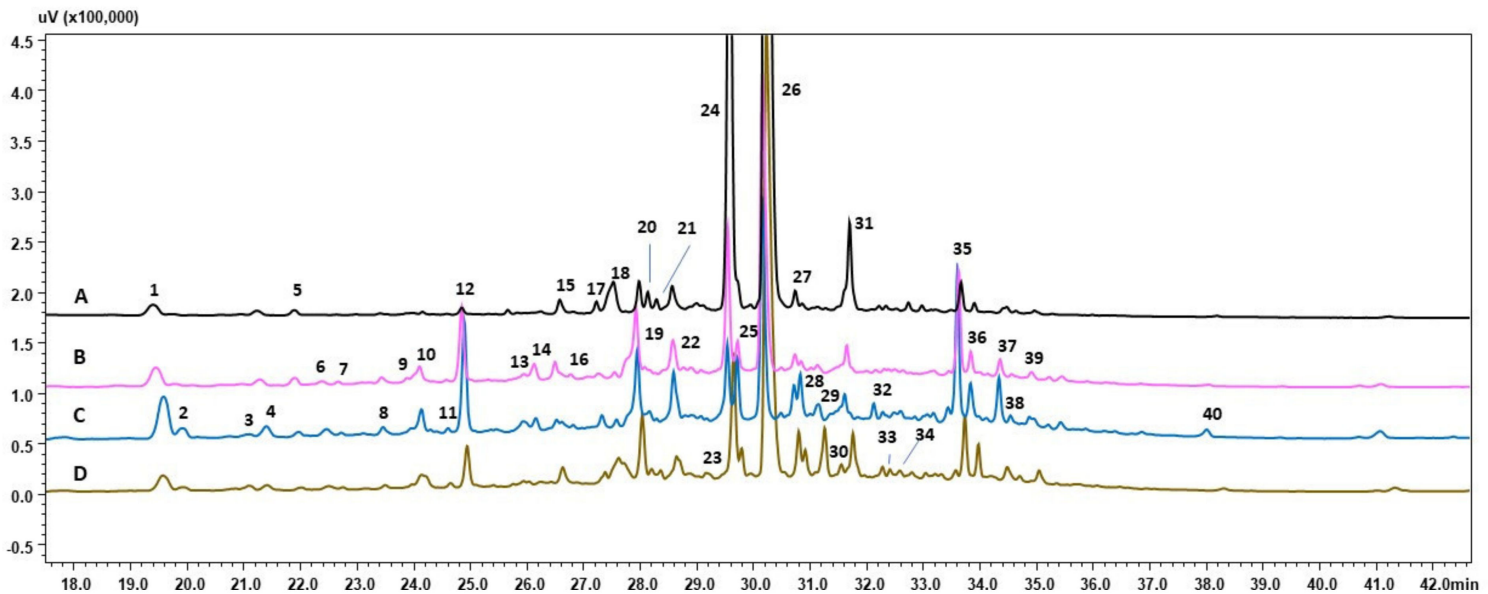

Figure 4. HPLC-PDA chromatograms (wavelength $320 \mathrm{~nm}$ ) of RgTR17 line root extracts: (A) 28-dayold (time zero); (B) 14-day old untreated roots-control; (C) roots treated 14 days with drought stress; (D) roots treated 14 days with cold stress. 
Table 5. HPLC-PDA-ESI-HRMS data on detected compounds in RgAR root extracts derived from various culture conditions.

\begin{tabular}{|c|c|c|c|c|c|}
\hline $\begin{array}{c}\text { Peak } \\
\text { No. }\end{array}$ & $\operatorname{Tr}$ & {$[\mathbf{M}-\mathbf{H}]^{-}$} & $\begin{array}{l}\text { Molecular } \\
\text { Formula }\end{array}$ & Compound & Conditions \\
\hline 1 & 19.39 & 179 & $\mathrm{C} 9 \mathrm{H} 8 \mathrm{O} 4$ & Caffeic acid & DZ; control; DS; CS \\
\hline \multirow{2}{*}{2} & \multirow{2}{*}{19.88} & 329 & $\mathrm{C} 15 \mathrm{H} 22 \mathrm{O} 8$ & Bartsioside & \multirow{2}{*}{ DS } \\
\hline & & 341 & C15H18O9 & Caffeic acid 3-glucoside & \\
\hline 3 & 21.22 & 431 & $\mathrm{C} 20 \mathrm{H} 24 \mathrm{~N} 4 \mathrm{O} 7$ & Unidentified & DZ; control; DS; CS \\
\hline 4 & 21.90 & 375 & C18H16O9 & Limocitrol & $\mathrm{DZ}$ \\
\hline 5 & 23.46 & 499 & $\mathrm{C} 22 \mathrm{H} 28 \mathrm{O} 13$ & Haploperoside & DS \\
\hline \multirow{2}{*}{6} & \multirow{2}{*}{24.13} & 509 & $\mathrm{C} 33 \mathrm{H} 18 \mathrm{O} 6$ & Unidentified & \multirow{2}{*}{ control; DS } \\
\hline & & 553 & $\mathrm{C} 27 \mathrm{H} 22 \mathrm{O} 13$ & Unidentified & \\
\hline \multirow{4}{*}{7} & \multirow{4}{*}{24.89} & 269 & $\mathrm{C} 16 \mathrm{H} 14 \mathrm{O} 4$ & Imperatorin & \multirow{4}{*}{ DZ; control; DS; CS } \\
\hline & & 313 & C17H14O6 & Crisimaritin & \\
\hline & & 627 & $\mathrm{C} 34 \mathrm{H} 28 \mathrm{O} 12$ & Unidentified & \\
\hline & & 715 & $\mathrm{C} 36 \mathrm{H} 28 \mathrm{O} 16$ & Dehydrorabdosiin & \\
\hline 8 & 26.58 & 733 & $\mathrm{C} 54 \mathrm{H} 22 \mathrm{O} 4$ & Unidentified & DZ; control; DS; CS \\
\hline 9 & 27.24 & 515 & $\mathrm{C} 26 \mathrm{H} 32 \mathrm{~N} 2 \mathrm{O} 9$ & Strictosidinic acid? & DZ; DS; CS \\
\hline 10 & 27.54 & 436 & $\mathrm{C} 25 \mathrm{H} 31 \mathrm{~N} 3 \mathrm{O} 4$ & $\begin{array}{l}\mathrm{N} 1, \mathrm{~N} 10-\mathrm{Bis}(\mathrm{p}- \\
\text { coumaroyl)spermidine }\end{array}$ & $\mathrm{DZ}$ \\
\hline \multirow{2}{*}{11} & \multirow{2}{*}{27.99} & 537 & $\mathrm{C} 27 \mathrm{H} 22 \mathrm{O} 12$ & Globoidnan B & \multirow{2}{*}{ DZ; control; DS; CS } \\
\hline & & 545 & $\mathrm{C} 32 \mathrm{H} 34 \mathrm{O} 8$ & Vittarin E & \\
\hline 12 & 28.14 & $439(2-)$ & C28H32N16O8 & Unidentified & $\mathrm{DZ}$ \\
\hline \multirow{2}{*}{13} & \multirow{2}{*}{28.29} & 435 & C20H20O11 & Irisxanthone & \multirow{2}{*}{ DZ } \\
\hline & & 521 & $\mathrm{C} 24 \mathrm{H} 26 \mathrm{O} 13$ & Iridin & \\
\hline \multirow[t]{5}{*}{14} & \multirow[t]{5}{*}{28.57} & 359 & C18H16O8 & Irigenin & \multirow[t]{5}{*}{ DZ; control; DS; CS } \\
\hline & & 369 & C21H18N6O or & Unidentified or & \\
\hline & & 483 & C20H22N2O5 & Apabetalone & \\
\hline & & & $\mathrm{C} 22 \mathrm{H} 28 \mathrm{O} 12$ & Rubinaphthin B/7-methyl-1,4,5- & \\
\hline & & & & $\begin{array}{l}\text { naphthalenetriol-4-[xylosyl- }(1 \rightarrow 6)- \\
\text { glucoside]/MEGxp0_002017 }\end{array}$ & \\
\hline 15 & 29.55 & 359 & $\mathrm{C} 18 \mathrm{H} 16 \mathrm{O} 8$ & Rosmarinic acid & DZ; control; DS; CS \\
\hline \multirow{3}{*}{16} & \multirow{3}{*}{29.71} & 447 & $\mathrm{C} 22 \mathrm{H} 24 \mathrm{O} 10$ & Sakuranin or Androechin & \multirow{3}{*}{ DS; CS } \\
\hline & & 461 & $\mathrm{C} 22 \mathrm{H} 22 \mathrm{O} 11$ & Azalein or Tectoridin & \\
\hline & & 627 & $\mathrm{C} 28 \mathrm{H} 36 \mathrm{O} 16$ & Piloside A & \\
\hline 17 & 30.11 & 717 & C36H30O16 & Lithospermic B acid & DZ; control; DS; CS \\
\hline 18 & 30.71 & 383 & $\begin{array}{l}\text { C21H24N2O5 or } \\
\text { C22H20N6O }\end{array}$ & Unidentified & DZ; control; DS; CS \\
\hline \multirow[t]{3}{*}{19} & \multirow[t]{3}{*}{30.83} & 335 & C17H20O7 & Unidentified & \multirow[t]{3}{*}{ DZ; control; DS; CS } \\
\hline & & 461 & $\mathrm{C} 22 \mathrm{H} 22 \mathrm{O} 11$ & Azalein & \\
\hline & & 557 & $\mathrm{C} 25 \mathrm{H} 34 \mathrm{O} 14$ & $\begin{array}{c}\text { Peujaponiside or Macrophylloside } \\
\text { D }\end{array}$ & \\
\hline 20 & 31.66 & 551 & $\mathrm{C} 28 \mathrm{H} 24 \mathrm{O} 12$ & Schizotenuin F & DZ; control; DS; CS \\
\hline \multirow{2}{*}{21} & 3363 & 465 & $\mathrm{C} 22 \mathrm{H} 26 \mathrm{O} 11$ & Curculigoside & D7. sontrol. DS. CS \\
\hline & 33.63 & 613 & C29H42O14 & Unidentified & DZ; control; DS;CS \\
\hline 22 & 33.82 & 611 & С29H40O14 & Unidentified & control; DS; CS \\
\hline & & 669 & $\mathrm{C} 35 \mathrm{H} 24 \mathrm{O} 14$ & S-(+)-skyrin-6-O-alpha- & \\
\hline & & 765 & $\mathrm{C} 48 \mathrm{H} 46 \mathrm{O} 9$ & arabinofuranoside & \\
\hline & & & & Unidentified & \\
\hline
\end{tabular}


Table 5. Cont.

\begin{tabular}{cccccc}
\hline $\begin{array}{c}\text { Peak } \\
\text { No. }\end{array}$ & Tr & {$[\mathbf{M}-\mathbf{H}]^{-}$} & $\begin{array}{c}\text { Molecular } \\
\text { Formula }\end{array}$ & Compound & Conditions \\
\hline 23 & 34.33 & 449 & C22H26O10 & $\begin{array}{c}\text { Auriculoside or } \\
\text { 4-methoxyphlorizin }\end{array}$ & DS; CS \\
\hline 24 & 34.87 & 451 & C23H32O9 & Unidentified & DS; CS \\
\hline 25 & 37.99 & 303 & C16H16O6 & Unidentified & DS \\
\hline 26 & 41.07 & 215 & C13H12O3 & Unidentified & DS \\
\hline
\end{tabular}

DZ-28-old day roots (day zero); Control-14-day-old untreated roots; DS—roots treated with drought stress for 14 days; CS-roots treated with cold stress for 14 days.

Table 6. HPLC-PDA-ESI-HRMS data on detected compounds in RgTR7 root extracts derived from various culture conditions.

\begin{tabular}{|c|c|c|c|c|c|}
\hline $\begin{array}{l}\text { Peak } \\
\text { No. }\end{array}$ & $\operatorname{Tr}$ & {$[\mathrm{M}-\mathrm{H}]^{-}$} & $\begin{array}{l}\text { Molecular } \\
\text { Formula }\end{array}$ & Compound & Sample No. \\
\hline 1 & 19.43 & 179 & $\mathrm{C} 9 \mathrm{H} 8 \mathrm{O} 4$ & Caffeic acid & DZ, control, DS, CS \\
\hline \multirow{2}{*}{2} & \multirow{2}{*}{19.78} & 329 & $\mathrm{C} 15 \mathrm{H} 22 \mathrm{O} 8$ & Bartsioside & \multirow{2}{*}{ control, DS, CS } \\
\hline & & 341 & $\mathrm{C} 15 \mathrm{H} 18 \mathrm{O} 9$ & Caffeic acid 3-glucoside & \\
\hline 3 & 21.27 & 431 & C19H28O11 & Zizybeoside I & control, DS, CS \\
\hline 4 & 21.90 & 519 & $\mathrm{C} 29 \mathrm{H} 28 \mathrm{O} 9$ & Unidentified & DS, CS \\
\hline \multirow[t]{9}{*}{5} & \multirow[t]{9}{*}{22.40} & 271 & C15H12O5 & Naringenin & \multirow[t]{9}{*}{ control } \\
\hline & & 297 & $\mathrm{C} 16 \mathrm{H} 10 \mathrm{O} 6$ & Irilone or Trifoliol or 3,8-dihydroxy- & \\
\hline & & & & $\begin{array}{l}\text { 1-methylanthraquinone-2-caroxylic } \\
\text { acid }\end{array}$ & \\
\hline & & 299 & $\mathrm{C} 14 \mathrm{H} 12 \mathrm{~N} 4 \mathrm{O} 4$ & & \\
\hline & & 415 & $\mathrm{C} 18 \mathrm{H} 24 \mathrm{O} 11$ & & \\
\hline & & \multirow{4}{*}{553} & & Unidentified & \\
\hline & & & & Regaloside L or & \\
\hline & & & С25H30O14 & Carbomethoxyferuoyl sorbitol & \\
\hline & & & \multicolumn{2}{|r|}{ Isoligusrosidic acid or Aquilarisinin } & \\
\hline \multirow{3}{*}{6} & \multirow{3}{*}{22.69} & 431 & $\mathrm{C} 18 \mathrm{H} 24 \mathrm{O} 12$ & Griselinoside & \multirow{3}{*}{ control, DS } \\
\hline & & 483 & $\mathrm{C} 22 \mathrm{H} 28 \mathrm{O} 12$ & Rubinaphthin B & \\
\hline & & 579 & С $32 \mathrm{H} 36 \mathrm{O} 10$ & Unidentified & \\
\hline \multirow{4}{*}{7} & \multirow{4}{*}{23.41} & 373 & $\mathrm{C} 16 \mathrm{H} 22 \mathrm{O} 10$ & Unidentified & \multirow{4}{*}{ control, DS, CS } \\
\hline & & 399 & C18H24O10 & Regaloside & \\
\hline & & 475 & $\mathrm{C} 23 \mathrm{H} 24 \mathrm{O} 11$ & Cirsimarin & \\
\hline & & 519 & $\mathrm{C} 24 \mathrm{H} 24 \mathrm{O} 13$ & Eujambolin or Purifolin & \\
\hline 8 & 23.90 & 499 & $\mathrm{C} 22 \mathrm{H} 28 \mathrm{O} 13$ & Haploperoside & control, DS \\
\hline \multirow{4}{*}{9} & \multirow{4}{*}{24.23} & 337 & $\mathrm{C} 16 \mathrm{H} 18 \mathrm{O} 8$ & Coumaroylquinic acid I or II & \multirow{4}{*}{ control, DS, CS } \\
\hline & & 467 & $\mathrm{C} 15 \mathrm{H} 32 \mathrm{O} 16$ & Unidentified & \\
\hline & & 509 & $\mathrm{C} 26 \mathrm{H} 22 \mathrm{O} 11$ & Unidentified & \\
\hline & & 553 & $\mathrm{C} 27 \mathrm{H} 22 \mathrm{O} 13$ & Unidentified & \\
\hline \multirow{3}{*}{10} & \multirow{3}{*}{24.57} & 501 & $\mathrm{C} 24 \mathrm{H} 22 \mathrm{O} 12$ & Malonyldaidzin & \multirow{3}{*}{ control, DS, CS } \\
\hline & & 597 & С26H30O16 & Swertiapuniside & \\
\hline & & 699 & С33H32O17 & Unidentified & \\
\hline
\end{tabular}


Table 6. Cont.

\begin{tabular}{|c|c|c|c|c|c|}
\hline $\begin{array}{l}\text { Peak } \\
\text { No. }\end{array}$ & $\operatorname{Tr}$ & {$[\mathrm{M}-\mathrm{H}]^{-}$} & $\begin{array}{l}\text { Molecular } \\
\text { Formula }\end{array}$ & Compound & Sample No. \\
\hline 11 & 24.83 & $\begin{array}{l}269 \\
313 \\
627 \\
671 \\
715\end{array}$ & $\begin{array}{c}\mathrm{C} 16 \mathrm{H} 14 \mathrm{O} 4 \\
\mathrm{C} 17 \mathrm{H} 14 \mathrm{O} 6 \\
\mathrm{C} 34 \mathrm{H} 28 \mathrm{O} 12 \\
\mathrm{C} 30 \mathrm{H} 28 \mathrm{~N} 2 \mathrm{O} 16 \\
\mathrm{C} 36 \mathrm{H} 28 \mathrm{O} 16\end{array}$ & $\begin{array}{l}\text { Imperatorin } \\
\text { Crisimaritin } \\
\text { Unidentified } \\
\text { Unidentified } \\
\text { Dehydrorabdosiin }\end{array}$ & control, DS, CS \\
\hline 12 & 25.70 & 531 & $\mathrm{C} 38 \mathrm{H} 28 \mathrm{O} 3$ & Unidentified & CS \\
\hline 13 & 25.89 & 501 & $\mathrm{C} 22 \mathrm{H} 30 \mathrm{O} 13$ & Ferulic acid rutinoside & CS \\
\hline 14 & 26.13 & $\begin{array}{l}547 \\
581 \\
729\end{array}$ & $\begin{array}{l}\mathrm{C} 25 \mathrm{H} 28 \mathrm{~N} 2 \mathrm{O} 12 \\
\mathrm{C} 26 \mathrm{H} 30 \mathrm{O} 15 \\
\mathrm{C} 36 \mathrm{H} 26 \mathrm{O} 17\end{array}$ & $\begin{array}{c}\text { Unidentified } \\
\text { Gentiabavaroside or } \\
\text { Sophodibenzenoside A } \\
\text { Unidentified }\end{array}$ & DS \\
\hline 15 & 26.63 & 733 & C36H30O17 & Unidentified & $\mathrm{CS}$ \\
\hline 16 & 27.26 & $\begin{array}{l}515 \\
581 \\
717\end{array}$ & $\begin{array}{l}\mathrm{C} 26 \mathrm{H} 32 \mathrm{~N} 2 \mathrm{O} 9 \\
\mathrm{C} 26 \mathrm{H} 30 \mathrm{O} 15 \\
\mathrm{C} 36 \mathrm{H} 30 \mathrm{O} 16\end{array}$ & $\begin{array}{c}\text { Strictosidinic acid? } \\
\text { Gentiabavaroside or } \\
\text { Sophodibenzenoside A } \\
\text { Rabdosiin }\end{array}$ & DZ, control, CS \\
\hline 17 & 27.54 & $\begin{array}{l}436 \\
479\end{array}$ & $\begin{array}{l}\mathrm{C} 25 \mathrm{H} 31 \mathrm{~N} 3 \mathrm{O} 4 \\
\mathrm{C} 22 \mathrm{H} 24 \mathrm{O} 12\end{array}$ & $\begin{array}{l}\mathrm{N} 1, \mathrm{~N} 10-\mathrm{Bis}(\mathrm{p}- \\
\text { coumaroyl)spermidine }\end{array}$ & DZ, control, DS, CS \\
\hline 18 & 28.01 & 537 & $\mathrm{C} 27 \mathrm{H} 22 \mathrm{O} 12$ & Globoidnan B & DZ, control, DS, CS \\
\hline 19 & 28.17 & $\begin{array}{l}459 \\
879\end{array}$ & $\begin{array}{c}\mathrm{C} 20 \mathrm{H} 28 \mathrm{O} 12 \\
\mathrm{C} 38 \mathrm{H} 36 \mathrm{ON} 6 \mathrm{O} 19\end{array}$ & $\begin{array}{c}\text { Paeonolide or Apiopaeonoside } \\
\text { Unidentified }\end{array}$ & DZ, control, DS, CS \\
\hline 20 & 28.32 & 435 & C20H20O11 & $\begin{array}{l}\text { Irisxanthone or Homomangiferin or } \\
\text { Swertianolin }\end{array}$ & $\mathrm{DZ}, \mathrm{CS}$ \\
\hline 21 & 28.57 & $\begin{array}{l}369 \\
521 \\
715\end{array}$ & $\begin{array}{c}\mathrm{C} 19 \mathrm{H} 16 \mathrm{O} 9 \\
\mathrm{C} 24 \mathrm{H} 26 \mathrm{O} 13 \\
\mathrm{C} 36 \mathrm{H} 28 \mathrm{O} 16 \text { or } \\
\mathrm{C} 42 \mathrm{H} 24 \mathrm{O} 11\end{array}$ & $\begin{array}{c}\text { Unidentified } \\
\text { Rosmarinic acid hexoside } \\
\text { Dehydrorabdosiin }\end{array}$ & DZ, control, DS, CS \\
\hline 22 & 29.14 & 435 & C20H20O11 & $\begin{array}{l}\text { Irisxanthone or Homomangiferin or } \\
\text { Swertianolin }\end{array}$ & CS \\
\hline 23 & 29.65 & $\begin{array}{l}359 \\
493\end{array}$ & $\begin{array}{l}\mathrm{C} 18 \mathrm{H} 16 \mathrm{O} 8 \\
\mathrm{C} 26 \mathrm{H} 22 \mathrm{O} 10\end{array}$ & $\begin{array}{c}\text { Rosmarinic acid } \\
\text { Salvianolic acid A }\end{array}$ & DZ, control, DS, CS \\
\hline 24 & 29.71 & $\begin{array}{l}447 \\
627\end{array}$ & $\begin{array}{l}\mathrm{C} 22 \mathrm{H} 24 \mathrm{O} 10 \\
\mathrm{C} 28 \mathrm{H} 36 \mathrm{O} 16\end{array}$ & $\begin{array}{l}\text { Sakuranin or Androechin } \\
\text { Piloside A }\end{array}$ & control, DS \\
\hline 25 & 30.30 & 717 & $\mathrm{C} 36 \mathrm{H} 30 \mathrm{O} 16$ & Lithospermic B acid & DZ, control, DS, CS \\
\hline 26 & 30.74 & 383 & $\mathrm{C} 21 \mathrm{H} 24 \mathrm{~N} 2 \mathrm{O} 5$ & Unidentified & control, DS, CS \\
\hline 27 & 30.83 & 461 & $\mathrm{C} 22 \mathrm{H} 22 \mathrm{O} 11$ & Azalein & control, DS, CS \\
\hline 28 & 31.20 & 445 & $\mathrm{C} 22 \mathrm{H} 22 \mathrm{O} 10$ & Swertisin or Glycitin or Sissotrin & DZ, control, DS, CS \\
\hline 29 & 31.71 & 551 & $\mathrm{C} 28 \mathrm{H} 24 \mathrm{O} 12$ & Schizoteniun F & DZ, control, DS, CS \\
\hline 30 & 32.15 & $\begin{array}{l}493 \\
641\end{array}$ & $\begin{array}{l}\mathrm{C} 26 \mathrm{H} 22 \mathrm{O} 10 \\
\mathrm{C} 31 \mathrm{H} 30 \mathrm{O} 15\end{array}$ & $\begin{array}{l}\text { Dihydrogloboidnan A } \\
\text { Unidentified }\end{array}$ & DS, CS \\
\hline 31 & 32.64 & 311 & $\mathrm{C} 16 \mathrm{H} 8 \mathrm{O} 7$ & Unidentified & control, DS, CS \\
\hline 32 & 32.99 & 635 & C38H36O9 & Unidentified & DS, CS \\
\hline 33 & 33.66 & 613 & $\mathrm{C} 29 \mathrm{H} 42 \mathrm{O} 14$ & Unidentified & control, DS, CS \\
\hline
\end{tabular}


Table 6. Cont.

\begin{tabular}{|c|c|c|c|c|c|}
\hline $\begin{array}{c}\text { Peak } \\
\text { No. }\end{array}$ & $\operatorname{Tr}$ & {$[\mathrm{M}-\mathrm{H}]^{-}$} & $\begin{array}{l}\text { Molecular } \\
\text { Formula }\end{array}$ & Compound & Sample No. \\
\hline 34 & 33.90 & $\begin{array}{l}451 \\
765\end{array}$ & $\begin{array}{l}\text { C23H32O9 } \\
\text { C41H50O14 }\end{array}$ & $\begin{array}{l}\text { Unidentified } \\
\text { Unidentified }\end{array}$ & control, DS, CS \\
\hline 35 & 34.36 & 449 & $\mathrm{C} 22 \mathrm{H} 26 \mathrm{O} 10$ & Auriculoside & control, DS, CS \\
\hline 36 & 34.95 & $\begin{array}{l}275 \\
313 \\
451\end{array}$ & $\begin{array}{l}\mathrm{C} 15 \mathrm{H} 16 \mathrm{O} 5 \\
\mathrm{C} 17 \mathrm{H} 14 \mathrm{O} 6 \\
\mathrm{C} 23 \mathrm{H} 32 \mathrm{O} 9\end{array}$ & $\begin{array}{l}\text { Unidentified } \\
\text { Pityrogrammin } \\
\text { Unidentified }\end{array}$ & control, DS, CS \\
\hline
\end{tabular}

DZ—28-old day roots (day zero); Control-14-day-old untreated roots; DS—roots treated with drought stress for 14 days; CS-roots treated with cold stress for 14 days.

Table 7. HPLC-PDA-ESI-HRMS data on detected compounds in RgTR17 root extracts derived from various culture conditions.

\begin{tabular}{|c|c|c|c|c|c|}
\hline $\begin{array}{l}\text { Peak } \\
\text { No. }\end{array}$ & $\operatorname{Tr}$ & {$[\mathbf{M}-\mathbf{H}]^{-}$} & $\begin{array}{l}\text { Molecular } \\
\text { Formula }\end{array}$ & Compound & Sample No. \\
\hline 1 & 19.58 & 179 & $\mathrm{C} 9 \mathrm{H} 8 \mathrm{O} 4$ & Caffeic acid & DZ, control, DS, CS \\
\hline 2 & 19.91 & $\begin{array}{l}329 \\
341\end{array}$ & $\begin{array}{l}\mathrm{C} 15 \mathrm{H} 22 \mathrm{O} 8 \\
\mathrm{C} 15 \mathrm{H} 18 \mathrm{O} 9\end{array}$ & $\begin{array}{c}\text { Bartsioside } \\
\text { Caffeic acid 3-glucoside }\end{array}$ & control, DS, CS \\
\hline 3 & 21.10 & 431 & С19H28O11 & Zizybeoside I & DZ, control, DS, CS \\
\hline 4 & 21.40 & 499 & $\mathrm{C} 22 \mathrm{H} 28 \mathrm{O} 13$ & $\begin{array}{c}\text { 4-Methylumbelliferyl-beta-D- } \\
\text { lactoside or } \\
\text { Haploperoside }\end{array}$ & DZ, control, DS,CS \\
\hline 5 & 21.97 & 519 & $\mathrm{C} 22 \mathrm{H} 32 \mathrm{O} 14$ & Segetoside A & DZ, control, DS, CS \\
\hline 6 & 22.46 & $\begin{array}{l}271 \\
553\end{array}$ & $\begin{array}{l}\mathrm{C} 15 \mathrm{H} 12 \mathrm{O} 5 \\
\mathrm{C} 25 \mathrm{H} 30 \mathrm{O} 14\end{array}$ & $\begin{array}{c}\text { Naringenin } \\
\text { Isoligusrosidicacid or Aquilarisinin }\end{array}$ & control, DS, CS \\
\hline 7 & 22.72 & 483 & $\mathrm{C} 22 \mathrm{H} 28 \mathrm{O} 12$ & Rubinaphthin B & control, DS, DC \\
\hline 8 & 23.46 & 443 & $\mathrm{C} 26 \mathrm{H} 20 \mathrm{O} 7$ & Artomunoxanthentrione & $\begin{array}{l}\text { DZ, control, DS, } \\
\text { DC }\end{array}$ \\
\hline 9 & 23.96 & 499 & $\mathrm{C} 22 \mathrm{H} 28 \mathrm{O} 13$ & $\begin{array}{c}\text { 4-Methylumbelliferyl-beta-D- } \\
\text { lactoside or } \\
\text { Haploperoside }\end{array}$ & control, DS, DC \\
\hline 10 & 24.10 & $\begin{array}{l}509 \\
553\end{array}$ & $\begin{array}{l}\mathrm{C} 26 \mathrm{H} 22 \mathrm{O} 11 \\
\mathrm{C} 27 \mathrm{H} 22 \mathrm{O} 13\end{array}$ & $\begin{array}{l}\text { Pseudonocardone C } \\
\text { Unidentified }\end{array}$ & control, DS, DC \\
\hline 11 & 24.58 & 505 & С21H30O14 & Echisoside & $\begin{array}{l}\text { DZ, control, DS, } \\
\text { DC }\end{array}$ \\
\hline 12 & 24.85 & $\begin{array}{l}269 \\
313 \\
627 \\
715\end{array}$ & $\begin{array}{l}\mathrm{C} 16 \mathrm{H} 14 \mathrm{O} 4 \\
\mathrm{C} 17 \mathrm{H} 14 \mathrm{O} 6 \\
\mathrm{C} 34 \mathrm{H} 28 \mathrm{O} 12 \\
\mathrm{C} 36 \mathrm{H} 28 \mathrm{O} 16\end{array}$ & $\begin{array}{l}\text { Unidentified } \\
\text { Crisimaritin } \\
\text { Unidentified } \\
\text { Dehydrorabdosiin }\end{array}$ & $\begin{array}{l}\text { DZ, control, DS, } \\
\text { DC }\end{array}$ \\
\hline 13 & 25.95 & 501 & С22H30O13 & Ferulic acid rutinoside & control, DS \\
\hline 14 & 26.13 & $\begin{array}{l}227 \\
547 \\
581 \\
729\end{array}$ & $\begin{array}{l}\mathrm{C} 12 \mathrm{H} 12 \mathrm{~N} 4 \mathrm{O} \\
\mathrm{C} 30 \mathrm{H} 28 \mathrm{O} 10 \\
\mathrm{C} 26 \mathrm{H} 30 \mathrm{O} 15 \\
\mathrm{C} 36 \mathrm{H} 26 \mathrm{O} 17\end{array}$ & $\begin{array}{c}\text { Unidentified } \\
\text { 3,5-dihydroxyrottlerin } \\
\text { Gentiabavaroside or } \\
\text { Sophodibenzenoside A } \\
\text { Unidentified }\end{array}$ & control, DS \\
\hline
\end{tabular}


Table 7. Cont.

\begin{tabular}{|c|c|c|c|c|c|}
\hline $\begin{array}{l}\text { Peak } \\
\text { No. }\end{array}$ & $\operatorname{Tr}$ & {$[\mathbf{M}-\mathbf{H}]^{-}$} & $\begin{array}{l}\text { Molecular } \\
\text { Formula }\end{array}$ & Compound & Sample No. \\
\hline 15 & 26.50 & 733 & С $36 \mathrm{H} 30 \mathrm{O} 17$ & Unidentified & $\begin{array}{l}\text { DZ, control, DS, } \\
\text { DC }\end{array}$ \\
\hline 16 & 26.77 & $\begin{array}{l}439 \\
459 \\
501 \\
534\end{array}$ & $\begin{array}{l}\mathrm{C} 22 \mathrm{H} 32 \mathrm{O} 9 \\
\mathrm{C} 20 \mathrm{H} 28 \mathrm{O} 12 \\
\mathrm{C} 22 \mathrm{H} 30 \mathrm{O} 13 \\
\mathrm{C} 21 \mathrm{H} 17 \mathrm{NO} 7\end{array}$ & $\begin{array}{c}\text { Unidentified } \\
\text { Paeonolide or Apiopaeonoside } \\
\text { Micromelumoside B } \\
\text { Unidentified }\end{array}$ & control, DS \\
\hline 17 & 27.23 & 515 & С31H32O7 & Pannokin A & $\begin{array}{l}\text { DZ, control, DS, } \\
\text { DC }\end{array}$ \\
\hline 18 & 27.53 & 436 & $\mathrm{C} 25 \mathrm{H} 31 \mathrm{~N} 3 \mathrm{O} 4$ & Unidentified & $\begin{array}{l}\text { DZ, control, DS, } \\
\text { DC }\end{array}$ \\
\hline 19 & 27.93 & $\begin{array}{l}339 \\
459 \\
537\end{array}$ & $\begin{array}{l}\mathrm{C} 18 \mathrm{H} 12 \mathrm{O} 7 \\
\mathrm{C} 20 \mathrm{H} 28 \mathrm{O} 12 \\
\mathrm{C} 27 \mathrm{H} 22 \mathrm{O} 12\end{array}$ & $\begin{array}{c}\text { Grevilline B } \\
\text { Paeonolide or Apiopaeonoside } \\
\text { Globoidnan B }\end{array}$ & $\begin{array}{l}\text { DZ, control, DS, } \\
\text { DC }\end{array}$ \\
\hline 20 & 28.14 & $439(2+)$ & $\mathrm{C} 60 \mathrm{H} 32 \mathrm{O} 8$ & Unidentified & $\mathrm{DZ}, \mathrm{DS}, \mathrm{DC}$ \\
\hline 21 & 28.30 & 435 & C20H20O11 & $\begin{array}{l}\text { Irisxanthone or Homomangiferin or } \\
\text { Swertianolin }\end{array}$ & DZ, DS, DC \\
\hline 22 & 28.58 & $\begin{array}{l}359 \\
483 \\
715\end{array}$ & $\begin{array}{l}\mathrm{C} 18 \mathrm{H} 16 \mathrm{O} 8 \\
\mathrm{C} 22 \mathrm{H} 28 \mathrm{O} 12 \\
\mathrm{C} 36 \mathrm{H} 28 \mathrm{O} 16\end{array}$ & $\begin{array}{c}\text { Irigenin } \\
\text { Rubinaphthin B or } \\
\text { 3,4-dihydrocatalposide } \\
\text { Unidentified }\end{array}$ & $\begin{array}{l}\text { DZ, control, DS, } \\
\text { DC }\end{array}$ \\
\hline 23 & 29.16 & 435 & C20H20O11 & $\begin{array}{l}\text { Irisxanthone or Homomangiferin or } \\
\text { Swertianolin }\end{array}$ & $\mathrm{DZ}, \mathrm{DC}$ \\
\hline 24 & 29.55 & $\begin{array}{l}359 \\
493 \\
537\end{array}$ & $\begin{array}{l}\mathrm{C} 18 \mathrm{H} 16 \mathrm{O} 8 \\
\mathrm{C} 26 \mathrm{H} 22 \mathrm{O} 10 \\
\mathrm{C} 27 \mathrm{H} 22 \mathrm{O} 12\end{array}$ & $\begin{array}{c}\text { Rosmarinic acid } \\
\text { Salvianolic acid A } \\
\text { Lithospermic acid }\end{array}$ & $\begin{array}{l}\text { DZ, control, DS, } \\
\text { DC }\end{array}$ \\
\hline 25 & 29.72 & $\begin{array}{l}419 \\
447 \\
449 \\
627\end{array}$ & $\begin{array}{l}\mathrm{C} 20 \mathrm{H} 20 \mathrm{O} 10 \\
\mathrm{C} 22 \mathrm{H} 24 \mathrm{O} 10 \\
\mathrm{C} 17 \mathrm{H} 26 \mathrm{~N} 2 \mathrm{O} 12 \\
\mathrm{C} 28 \mathrm{H} 36 \mathrm{O} 16\end{array}$ & $\begin{array}{c}\text { Isogentisin 3-O-glucoside } \\
\text { Sakuranin or Androechin } \\
\text { Unidentified } \\
\text { Piloside A }\end{array}$ & control, DS, DC \\
\hline 26 & 30.17 & 717 & С36H30O16 & Lithospermic B acid & $\begin{array}{l}\text { DZ, control, DS, } \\
\text { DC }\end{array}$ \\
\hline 27 & 30.74 & 383 & $\mathrm{C} 26 \mathrm{H} 24 \mathrm{O} 3$ & Unidentified & $\begin{array}{l}\text { DZ, control, DS, } \\
\text { DC }\end{array}$ \\
\hline 28 & 30.86 & $\begin{array}{l}335 \\
465 \\
497 \\
533 \\
557 \\
611\end{array}$ & $\begin{array}{l}\text { C17H20O7 } \\
\mathrm{C} 22 \mathrm{H} 26 \mathrm{O} 11 \\
\mathrm{C} 16 \mathrm{H} 34 \mathrm{O} 17 \\
\mathrm{C} 29 \mathrm{H} 26 \mathrm{O} 10 \\
\mathrm{C} 25 \mathrm{H} 34 \mathrm{O} 14 \\
\mathrm{C} 27 \mathrm{H} 32 \mathrm{O} 16\end{array}$ & $\begin{array}{c}\text { Unidentified } \\
\text { Curculigoside } \\
\text { Unidentified } \\
\text { Unidentified } \\
\text { Peujaponiside } \\
\text { Hydroxysafflor yellow A }\end{array}$ & $\begin{array}{l}\text { DZ, control, DS, } \\
\text { DC }\end{array}$ \\
\hline 29 & 31.26 & 445 & $\mathrm{C} 22 \mathrm{H} 22 \mathrm{O} 10$ & Swertisin or Glycitin or Sissotrin & control, DS, DC \\
\hline 30 & 31.55 & $\begin{array}{l}475 \\
701\end{array}$ & $\begin{array}{c}\text { C23H24O11 } \\
\text { C35H30N2O14 }\end{array}$ & $\begin{array}{l}\text { Crisimarin or Kakkalidone } \\
\text { Unidentified }\end{array}$ & DC \\
\hline 31 & 31.69 & 551 & $\mathrm{C} 28 \mathrm{H} 24 \mathrm{O} 12$ & Schizoteniun F & $\begin{array}{l}\text { DZ, control, DS, } \\
\text { DC }\end{array}$ \\
\hline
\end{tabular}


Table 7. Cont.

\begin{tabular}{|c|c|c|c|c|c|}
\hline $\begin{array}{l}\text { Peak } \\
\text { No. }\end{array}$ & $\operatorname{Tr}$ & {$[\mathbf{M}-\mathbf{H}]^{-}$} & $\begin{array}{l}\text { Molecular } \\
\text { Formula }\end{array}$ & Compound & Sample No. \\
\hline 32 & 32.28 & $\begin{array}{l}320 \\
335 \\
507 \\
539 \\
641\end{array}$ & $\begin{array}{l}\text { C } 31 \mathrm{H} 30 \mathrm{O} 15 \\
\mathrm{C} 27 \mathrm{H} 44 \mathrm{O} 19 \\
\mathrm{C} 24 \mathrm{H} 28 \mathrm{O} 12 \\
\mathrm{C} 25 \mathrm{H} 32 \mathrm{O} 13 \\
\mathrm{C} 31 \mathrm{H} 30 \mathrm{O} 15\end{array}$ & $\begin{array}{c}\text { Unidentified } \\
\text { Unidentified } \\
\text { Specioside or } \\
\text { 10-O-cis-p-Coumaorylcatalpol } \\
\text { Oleuropein } \\
\text { Unidentified }\end{array}$ & DS, DC \\
\hline 33 & 32.41 & 465 & $\mathrm{C} 22 \mathrm{H} 26 \mathrm{O} 11$ & Curculigoside & DC \\
\hline 34 & 32.59 & 453 & С22H30O19 & Unidentified & DS, DC \\
\hline 35 & 33.67 & 613 & $\mathrm{C} 29 \mathrm{H} 42 \mathrm{O} 14$ & Unidentified & $\begin{array}{l}\text { DZ, control, DS, } \\
\text { DC }\end{array}$ \\
\hline 36 & 33.90 & $\begin{array}{l}435 \\
451 \\
669 \\
765\end{array}$ & $\begin{array}{c}\mathrm{C} 17 \mathrm{H} 12 \mathrm{~N} 10 \mathrm{O} 5 \\
\mathrm{C} 19 \mathrm{H} 28 \mathrm{~N} 6 \mathrm{O} 7 \\
\mathrm{C} 36 \mathrm{H} 26 \mathrm{O} 14 \\
\mathrm{C} 41 \mathrm{H} 50 \mathrm{O} 14\end{array}$ & $\begin{array}{l}\text { Unidentified } \\
\text { Unidentified } \\
\text { Unidentified } \\
\text { Unidentified }\end{array}$ & $\begin{array}{c}\text { DZ, control, DS, } \\
\text { DC }\end{array}$ \\
\hline 37 & 34.36 & 449 & $\mathrm{C} 22 \mathrm{H} 26 \mathrm{O} 10$ & Auriculoside & $\begin{array}{c}\text { DZ, control, DS, } \\
\text { DC }\end{array}$ \\
\hline 38 & 34.57 & 463 & $\mathrm{C} 22 \mathrm{H} 24 \mathrm{O} 11$ & Lanceolin or Scuteamoenoside & $\begin{array}{l}\text { DZ, control, DS, } \\
\text { DC }\end{array}$ \\
\hline 39 & 34.91 & 451 & $\mathrm{C} 23 \mathrm{H} 32 \mathrm{O} 9$ & Unidentified & $\begin{array}{l}\text { DZ, control, DS, } \\
\text { DC }\end{array}$ \\
\hline 40 & 38.01 & $\begin{array}{l}303 \\
479 \\
543\end{array}$ & $\begin{array}{l}\mathrm{C} 16 \mathrm{H} 16 \mathrm{O} 6 \\
\mathrm{C} 23 \mathrm{H} 28 \mathrm{O} 11 \\
\mathrm{C} 29 \mathrm{H} 36 \mathrm{O} 10\end{array}$ & $\begin{array}{c}\text { 3’-O-Methylcatechin } \\
\text { Unidentified } \\
\text { Unidentified }\end{array}$ & $\begin{array}{l}\text { DZ, control, DS, } \\
\text { DC }\end{array}$ \\
\hline
\end{tabular}

DZ-28-old day roots (day zero); Control-14-day-old untreated roots; DS-roots treated with drought stress for 14 days; CS—roots treated with cold stress for 14 days.

The results of current study suggest that root cultures of $R$. graeca could serve as a new and abundant source of LBA, the phenolic acid exhibiting various biological activities like lowering blood pressure [38], cytoprotective effects on pancreatic $\beta$-cells [39,40] and cardioprotective properties [41]. HPLC-PDA-ESI-HRMS analysis revealed differences in chemical profiles of investigated root lines that could be connected with their genetic diversity as well as be connected with stress factors used. Among abiotic stressors the cold had the most impact on accumulation of three selected phenolic acids, however effect of both used abiotic factors on their biosynthesis was not considerable. In conclusion, R. graeca roots, hairy and anatomical, are an interesting plant material for further phytochemical and biological exploitation. Further investigations are needed to identified other detected in root extracts molecules.

Supplementary Materials: The following supporting information can be downloaded at: https: / / www.mdpi.com/article/10.3390/cells11060931/s1, Figure S1: Validation parameters of HPLC method., Table S1: Mass spectra of compounds detected in extracts of RgAR root line; Table S2: Mass spectra of compounds detected in extracts of RgTR7 root line; Table S3: Mass spectra of compounds detected in extracts of RgTR17 root line; Table S4 HRMS data for investigated methanolic extracts.

Author Contributions: Conceptualization, M.R.N. and K.S.-B.; methodology, M.R.N., B.W. and K.S.B.; validation, B.W.; formal analysis, M.R.N., B.W. and K.S.-B.; investigation, M.R.N. and B.W.; data curation, M.R.N., B.W. and K.S.-B.; writing-original draft preparation, M.R.N., B.W. and K.S.-B.; writing—review and editing, A.M. and A.P.; visualization, M.R.N. and B.W.; supervision, K.S.-B. All authors have read and agreed to the published version of the manuscript.

Funding: This research received no external funding.

Institutional Review Board Statement: Not applicable. 


\section{Informed Consent Statement: Not applicable.}

Data Availability Statement: The data presented in this study are available on request from the corresponding author. The data are not publicly available because they are a part of one of co-authors habilitation work and after finishing this work the data will be accessible.

Acknowledgments: Authors are grateful to Janusz Mazur M.Sc. for ion concentration determination by atomic absorption spectrometry.

Conflicts of Interest: The authors declare no conflict of interest.

\section{References}

1. Wilson, S.A.; Roberts, S.C. Recent advances towards development and commercialization of plant cell culture processes for the synthesis of biomolecules. Plant Biotechnol. J. 2012, 10, 249-268. [CrossRef] [PubMed]

2. Georgiev, V.; Slavov, A.; Vasileva, I.; Pavlov, A. Plant cell culture as emerging technology for production of active cosmetic ingredients. Eng. Life Sci. 2018, 18, 779-798. [CrossRef]

3. Babich, O.; Sukhikh, S.; Pungin, A.; Ivanova, S.; Asyakina, L.; Prosekov, A. Modern trends in the in vitro production and use of callus, suspension cells and root cultures of medicinal plants. Molecules 2020, 25, 5805. [CrossRef] [PubMed]

4. Li, Y.; Kong, D.; Fu, Y.; Sussman, M.R.; Wu, H. The effect of developmental and environmental factors on secondary metabolites in medicinal plants. Plant Physiol. Biochem. 2020, 148, 80-89. [CrossRef] [PubMed]

5. Kamari, G.; Blanché, C.; Siljak-Yakovlev, S. Mediterranean chromosome number reports—24. Flora Mediterr. 2014, $24,286-291$. [CrossRef]

6. Walter, K.S.; Gillett, H.J. 1997 IUCN Red List of Threatened Plants; Walter, K.S., Gillett, H.J., Eds.; Complied by the World Conservation Monitoring Centre; IUCN-The World Conservation Union: Gland, Switzerland; Cambridge, UK, 1998; ISBN 2-8317-0328-X.

7. Ganos, C.; Aligiannis, N.; Chinou, I.; Naziris, N.; Chountoulesi, M.; Mroczek, T.; Graikou, K. Rindera graeca (Boraginaceae) phytochemical profile and biological activities. Molecules 2020, 25, 3625. [CrossRef]

8. Sykłowska-Baranek, K.; Pietrosiuk, A.; Graikou, K.; Damianakos, H.; Jeziorek, M.; Chinou, I. Phenolic compounds from in vitro cultures of Rindera graeca Boiss. \& Feldr. Planta Med. 2013, 79, 1187. [CrossRef]

9. Sykłowska-Baranek, K.; Pietrosiuk, A.; Szyszko, E.; Graikou, K.; Jeziorek, M.; Kuźma, Ł.; Chinou, I. Phenolic compounds from in vitro cultures of Rindera graeca Boiss. \& Heldr. Planta Med. 2012, 78, 1221. [CrossRef]

10. Sykłowska-Baranek, K.; Pietrosiuk, A.; Kuźma, Ł.; Chinou, I.; Kongel, M.; Jeziorek, M. Establishment of Rindera graeca transgenic root culture as a source of shikonin derivatives. Planta Med. 2008, 74, 1161. [CrossRef]

11. Graikou, K.; Damianakos, H.; Ganos, C.; Sykłowska-Baranek, K.; Jeziorek, M.; Pietrosiuk, A.; Roussakis, C.; Chinou, I. Chemical profile and screening of bioactive metabolites of Rindera graeca (A. DC.) Bois. \& Heldr. (Boraginaceae) in vitro cultures. Plants 2021, 10, 834. [CrossRef]

12. Jeziorek, M.; Damianakos, H.; Kawiak, A.; Laudy, A.E.; Zakrzewska, K.; Sykłowska-Baranek, K.; Chinou, I.; Pietrosiuk, A. Bioactive rinderol and cynoglosol isolated from Cynoglossum columnae Ten. in vitro root culture. Ind. Crop. Prod. 2019, 137, 446-452. [CrossRef]

13. Kawka, M.; Bubko, I.; Koronkiewicz, M.; Gruber-Bzura, B.; Graikou, K.; Chinou, I.; Jeziorek, M.; Pietrosiuk, A.; SykłowskaBaranek, K. Polyurethane foam rafts supported in vitro cultures of Rindera graeca roots for enhanced production of rinderol, potent proapoptotic naphthoquinone compound. Int. J. Mol. Med. 2022, 23, 56. [CrossRef] [PubMed]

14. Altundag, E.; Ozturk, M. Ethnomedicinal studies on the plant resources of east Anatolia, Turkey. Procedia Soc. Behav. Sci. 2011, 19, 756-777. [CrossRef]

15. Civra, A.; Francese, R.; Sinato, D.; Donalisio, M.; Cagno, V.; Rubiolo, P.; Ceylan, R.; Uysal, A.; Zengin, G.; Lembo, D. In vitro screening for antiviral activity of Turkish plants revealing methanolic extract of Rindera lanata var. lanata active against human rotavirus. BMC Complement. Altern. Med. 2017, 17, 1-8. [CrossRef]

16. Yücel, T.B.; Karaoğlu, Ş.A.; Yaylı, N. Antimicrobial activity and composition of Rindera lanata (LAM.) Bunge var. canescens (A.D.C.) Kosn. essential oil obtained by hydrodistillation and microwave assisted distillation. Rec. Nat. Prod. $2017,11,328-333$.

17. Selmar, D.; Kleinwächter, M. Influencing the product quality by deliberately applying drought stress during the cultivation of medicinal plants. Ind. Crops Prod. 2013, 42, 558-566. [CrossRef]

18. Taiz, L.; Zeiger, E. Secondary metabolites and plant defense. In Plant Physiology; Taiz, L., Zeiger, E., Eds.; Sinauer: Sunderland, MA, USA, 2002; Volume 3, pp. 283-308. ISBN 0878938230.

19. Aguirre-Becerra, H.; Vazquez-Hernandez, M.C.; Saenz de la O, D.; Alvarado-Mariana, A.G.; Guevara-Gonzalez, R.; Fernando Garcia-Trejo, J.; Feregrino-Perez, A.A. Role of Stress and Defense in Plant Secondary Metabolites Production. In Bioactive Natural Products for Pharmaceutical Applications; Pal, D., Nayak, A.K., Eds.; Springer Nature: Cham, Switzerland, 2021; Volume 140, pp. 151-195. [CrossRef]

20. Gupta, P.K.; Durzan, D.J. Shoot multiplication from mature trees of Douglas-fir (Pseudotsuga menziesii) and sugar pine (Pinus lambertiana). Plant Cell Rep. 1985, 4, 177-179. [CrossRef] 
21. Pękal, A.; Pyrzynska, K. Evaluation of aluminium complexation reaction for flavonoid content Assay. Food Anal. Methods 2014, 7, 1776-1782. [CrossRef]

22. Aghaee, A.; Moradi, F.; Zare-Maivan, H.; Zarinkamar, F.; Irandoost, H.P.; Sharifi, P. Physiological responses of two rice (Oryza sativa L.) genotypes to chilling stress at seedling stage. African J. Biotechnol. 2011, 10, 7617-7621. [CrossRef]

23. Örvar, B.L.; Sangwan, V.; Omann, F.; Dhindsa, R.S. Early steps in cold sensing by plant cells: The role of actin cytoskeleton and membrane fluidity. Plant J. 2000, 23, 785-794. [CrossRef]

24. Dai, J.; Mumper, R.J. Plant phenolics: Extraction, analysis and their antioxidant and anticancer properties. Molecules 2010, 15, 7313-7352. [CrossRef] [PubMed]

25. Dias, M.I.; Sousa, M.J.; Alves, R.C.; Ferreira, I.C.F.R. Exploring plant tissue culture to improve the production of phenolic compounds: A review. Ind. Crops Prod. 2016, 82, 9-22. [CrossRef]

26. Bulgakov, V.P.; Vereshchagina, Y.V.; Veremeichik, G.N. Anticancer polyphenols from cultured plant cells: Production and new bioengineering strategies. Curr. Med. Chem. 2018, 25, 4671-4692. [CrossRef] [PubMed]

27. Yamamoto, H.; Yazaki, K.; Inoue, K. Simultaneous analysis of shikimate-derived secondary metabolites in Lithospermum erythrorhizon cell suspension cultures by high-performance liquid chromatography. J. Chromatogr. B Biomed. Sci. Appl. 2000, 738, 3-15. [CrossRef]

28. Ramakrishna, A.; Ravishankar, G.A. Influence of abiotic stress signals on secondary metabolites in plants. Plant Signal. Behav. 2011, 6, 1720-1731.

29. Isah, T. Stress and defense responses in plant secondary metabolites production. Biol. Res. 2019, 52, 39. [CrossRef]

30. Kleinwächter, M.; Selmar, D. New insights explain that drought stress enhances the quality of spice and medicinal plants: Potential applications. Agron. Sustain. Dev. 2015, 35, 121-131. [CrossRef]

31. Mierziak, J.; Kostyn, K.; Kulma, A. Flavonoids as important molecules of plant interactions with the environment. Molecules 2014, 19, 16240-16265. [CrossRef]

32. Kapoor, D.; Bhardwaj, S.; Landi, M.; Sharma, A.; Ramakrishnan, M.; Sharma, A. The impact of drought in plant metabolism: How to exploit tolerance mechanisms to increase crop production. Appl. Sci. 2020, 10, 5692. [CrossRef]

33. Simic, M.R.; Vuckovic, I.; Trifunovic, S.S. Pyrrolizidine alkaloids and fatty acids from the endemic plant species Rindera umbellata and the effect of lindelofine-N-oxide on tubulin polymerization. Molecules 2014, 18, 10694-10706. [CrossRef]

34. Mandić, B.M.; Vlajić, M.D.; Trifunović, S.S.; Simić, R.; Vujisić, L.V.; Vučković, I.M.; Novaković, M.M.; Nikolić-Mandić, S.D.; Teševic, V.V.; Vajs, V.V.; et al. Optimisation of isolation procedure for pyrrolizidine alkaloids from Rindera umbellata Bunge. Nat. Prod. Res. Former. Nat. Prod. Lett. 2015, 29, 887-890. [CrossRef]

35. Yamamoto, H.; Zhao, P.; Yazaki, K.; Inoue, K. Regulation of lithospermic acid B and shikonin production in Lithospermum erythrorhizon cell suspension cultures. Chem. Pharm. Bull. 2002, 50, 1086-1090. [CrossRef] [PubMed]

36. Bednarek, P.T.; Orłowska, R. Plant tissue culture environment as a switch-key of (epi)genetic changes. Plant Cell. Tissue Organ Cult. 2020, 140, 245-257. [CrossRef]

37. Fu, C.; Li, L.; Wu, W.; Li, M.; Yu, X.; Yu, L. Assessment of genetic and epigenetic variation during long-term Taxus cell culture. Plant Cell Rep. 2012, 31, 1321-1331. [CrossRef]

38. Kang, D.G.; Oh, H.; Chung, H.T.; Lee, H.S. Inhibition of angiotensin converting enzyme by lithospermic acid B isolated from Radix Salviae miltiorrhiza Bunge. Phytother. Res. 2003, 17, 917-920. [CrossRef]

39. Lee, B.W.; Chun, S.W.; Kim, S.H.; Lee, Y.; Kang, E.S.; Cha, B.S.; Lee, H.C. Lithospermic acid B protects beta-cells from cytokineinduced apoptosis by alleviating apoptotic pathways and activating anti-apoptotic pathways of Nrf2-HO-1 and Sirt1. Toxicol. Appl. Pharmacol. 2011, 252, 47-54. [CrossRef]

40. Jin, C.J.; Yu, S.H.; Wang, X.M.; Woo, S.J.; Park, H.J.; Lee, H.C.; Choi, S.H.; Kim, K.M.; Kim, J.H.; Park, K.S.; et al. The effect of lithospermic acid, an antioxidant, on development of diabetic retinopathy in spontaneously obese diabetic rats. PLoS ONE 2014, 9, e98232. [CrossRef]

41. Wang, J.; Xiong, X.; Feng, B. Cardiovascular effects of salvianolic acid B. Evidence-based Complement. Altern. Med. 2013, 2013, 247948. [CrossRef] 